\title{
A Prolonged High-Salinity Event in the Northern Arabian Sea during 2014-17
}

\author{
YUHONG ZHANG, ${ }^{\mathrm{a}, \mathrm{c}}$ YAN DU, ${ }^{\mathrm{a}, \mathrm{b}, \mathrm{c}}$ W. N. D. S JAYARATHNA, ${ }^{\mathrm{a}, \mathrm{b}}$ QIWEI SUN, ${ }^{\mathrm{a}, \mathrm{b}, \mathrm{c}}$ YING ZHANG, ${ }^{\mathrm{a}, \mathrm{c}}$ \\ FENGCHAO YAO, ${ }^{\mathrm{d}}$ AND MING FENG ${ }^{\mathrm{e}, \mathrm{f}}$ \\ ${ }^{a}$ State Key Laboratory of Tropical Oceanography, South China Sea Institute of Oceanology, \\ Chinese Academy of Sciences, Guangzhou, China \\ ${ }^{\mathrm{b}}$ University of Chinese Academy of Sciences, Beijing, China \\ ${ }^{\mathrm{c}}$ Southern Marine Science and Engineering Guangdong Laboratory, Guangzhou, China \\ ${ }^{\mathrm{d}}$ Biological and Environmental Science and Engineering Division, King Abdullah University of \\ Science and Technology, Thuwal, Saudi Arabia \\ ${ }^{\text {e } C S I R O}$ Oceans and Atmosphere, Crawley, Western Australia, Australia \\ ${ }^{\mathrm{f}}$ Centre for Southern Hemisphere Oceans Research, Hobart, Tasmania, Australia
}

(Manuscript received 10 September 2019, in final form 29 December 2019)

\begin{abstract}
A prolonged high-salinity event in the northern Arabian Sea, to the east of the Gulf of Oman, during 2014-17 was identified based on Argo datasets. The prolonged event was manifested as enhanced spreading of the surface Arabian Sea high-salinity water and the intermediate Persian Gulf water. We used satellite altimetric data and geostrophic current data to understand the oceanic processes and the salt budget associated with the high-salinity event. The results indicated that the strengthened high-salinity advection from the Gulf of Oman was one of the main causes of the salinity increase in the northern Arabian Sea. The changes of the seasonally dependent eddies near the mouth of the Gulf of Oman dominated the strengthened high-salinity advection during the event as compared with the previous 4-yr period: the westward shifted cyclonic eddy during early winter stretched to the remote western Gulf of Oman, which carried the higher-salinity water to the northern Arabian Sea along the south coast of the Gulf. An anomalous eddy dipole during early summer intensified the eastward Ras Al Hadd Jet and its high-salinity advection into the northern Arabian Sea. In addition, the weakened low-salinity advection by coastal currents along the Omani coast caused by the weakened southwest monsoon contributed to the maintenance of the high-salinity event. This prolonged high-salinity event reflects the upper-ocean responses to the monsoon change and may affect the regional hydrography and biogeochemistry extensively.
\end{abstract}

\section{Introduction}

Three typical high-salinity water masses have been reported in the Arabian Sea: the Arabian Sea high-salinity water (ASHSW), the Persian Gulf water (PGW), and the Red Sea water (Morrison 1997; Rochford 1964; Stramma et al. 2002). The ASHSW forms in the northern part of the Arabian Sea and spreads southward as a salinity maximum within the upper $150 \mathrm{~m}$ (Kumar and Prasad 1996, 1999; Qasim 1982; Rochford 1964). The PGW forms in the Persian Gulf and exits to the Gulf of Oman through Strait of Hormuz, and then spreads to the northern Arabian Sea as an intermediate high-salinity water with its core on the $\sigma_{0}=26.5 \mathrm{~kg} \mathrm{~m}^{-3}$ layer, at $250-300 \mathrm{~m}$ (Morrison 1997; Prasad et al. 2001; Swift and Bower 2003;

\footnotetext{
Corresponding author: Yan Du, duyan@scsio.ac.cn
}

Yao and Johns 2010). The Red Sea water forms in the Red Sea and spreads to the Arabian Sea as a saline intermediate water with the core on the $\sigma_{0}=27.2 \mathrm{~kg} \mathrm{~m}^{-3}$ layer, in the depth range of 500-700 $\mathrm{m}$ (Beal et al. 2000; Jung et al. 2001; Shapiro and Meschanov 1991).

The northern Arabian Sea, north of about $19^{\circ} \mathrm{N}$, is surrounded by the arid south Asia continent. The region is predominantly influenced by the monsoon and characterized by an excess of evaporation over precipitation and complex ocean circulation (Fig. 1a). The ASHSW forms through deep convective mixing during winter (Han et al. 2001; McCreary et al. 1993; Prasad and Ikeda 2002a,b), when the wind blows from the dry and cold south Asia continent. Then, it is transported southward and the low-salinity water masses are advected northward by the West Indian Coastal Current during winter monsoon and the western currents along the Omani 
(a) annual mean

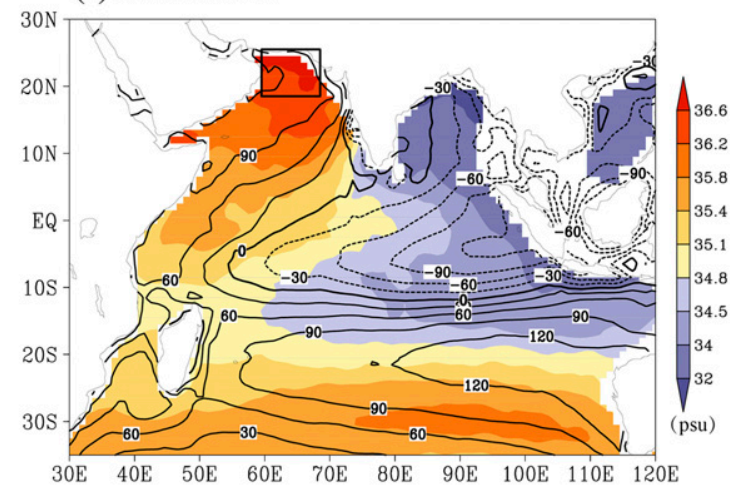

(b) seasonal cycle

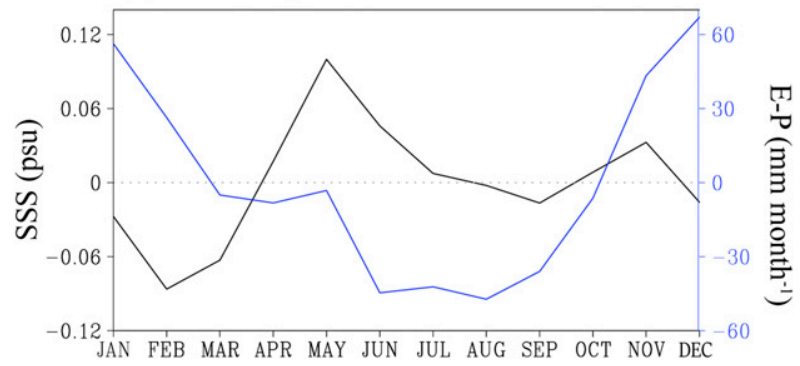

FIG. 1. Annual mean distributions and seasonal cycles of the Argo SSS and freshwater flux (evaporation minus precipitation $E-P$ ). (a) SSS (shaded; psu) and $E-P$ (contours; mm month ${ }^{-1}$ ) in the tropical and subtropical Indian Ocean, and (b) seasonal variability of the regional mean SSS (black curve) and $E-P$ (blue curve $)$ in the northern Arabian Sea $\left(59^{\circ}-68^{\circ} \mathrm{E}, 19^{\circ}-25^{\circ} \mathrm{N}\right)$. The bold rectangle in (a) shows the region used for the average in (b).

coast during summer monsoon to maintain the longterm salinity balance (Jensen 2003; Schott and McCreary 2001; Stramma et al. 2002).

During the winter monsoon (October-March), the prevailing wind is the northeast monsoon, which triggers a southward coastal current near the western boundary of the Arabian Sea and cyclonic eddies off the coastal region. The coastal currents advect the ASHSW southward to the equatorial region. Meanwhile, the West Indian Coastal Current flows northward (Schott and McCreary 2001; Stramma et al. 2002), advecting the low-salinity water that originated in the Bay of Bengal to the northern Arabian Sea.

In the summer season (April-September), the southwest monsoon prevails in the Arabian Sea, triggering strong upwelling and a negative sea surface height anomaly along the east Omani coast and an anticyclonic eddy in the off coastal regions (Manghnani et al. 1998; Shi et al. 1999). The upwelling occurs in the northern edge of the anticyclone, which advects low-salinity water originated in the southern Indian Ocean to the Omani coast region. Then, the upwelled low-salinity water is carried into the northern Arabian Sea and the Gulf of
Oman by the coastal currents and eddies. Meanwhile, the eastward currents are observed in the off coastal region of Oman (Schott and McCreary 2001), in which the Ras Al Hadd Jet flows into the open ocean near the mouth of the Gulf of Oman with a cyclone north of the jet and an anticyclone south of the jet (Böhm et al. 1999; Flagg and Kim 1998). These currents favor the spreading of the high-salinity water from the Gulf of Oman to the northern Arabian Sea.

The PGW spreads along the south coast of the Gulf of Oman (Prasad et al. 2001; Qasim 1982; Rochford 1964) and extends eastward to the northern Arabian Sea by the Ras Al Hadd Jet during spring and summer (Böhm et al. 1999). Observations and modeling studies have suggested that eddies play an important role in the spreading of the PGW water in the Gulf of Oman and the northern Arabian Sea (Carton et al. 2012; L'Hégaret et al. 2013, 2015). Especially the eddies near the mouth of the Gulf of Oman favor the high-salinity water transport from the Gulf of Oman to the northern Arabian Sea (L'Hégaret et al. 2013; Prasad and Ikeda 2002b; Wang et al. 2013). The wind stress curl over the Gulf of Oman and the westward propagating Rossby waves are crucial to the generation of the eddies near the mouth of the Gulf of Oman (L'Hégaret et al. 2013).

Previous works studied the water mass and the related dynamical processes based on sparse observations obtained from the International Indian Ocean Expedition (IIOE) in the 1960s (Levitus 1983; Wyrtki 1971) and cruises after that (Banse and Postel 2009; Varma et al. 1980), together with ocean numerical modeling (Koné et al. 2009; L'Hégaret et al. 2015; Prasad and Ikeda 2002a,b; Yao and Johns 2010). After 2000, the Array for Real-Time Geostrophic Oceanography (Argo) project provides more observations in the northern Arabian Sea to conduct detailed studies on the water mass and related ocean dynamics.

Joseph and Freeland (2005) used Argo float data to study the temporal and spatial variation of the ASHSW in the Arabian Sea. They suggested that both the ocean dynamics and the atmospheric coupling can affect the salinity variation. Wang et al. (2013) used Argo float data from December 2001 to December 2009 to study a short-term, high-salinity event in the northern Arabian Sea and the Gulf of Oman, forced by ocean advection related to a tropical cyclone and an eddy-like ocean circulation.

In this study, we depict a prolonged high-salinity event in the northern Arabian Sea: the surface and intermediate layer high-salinity water increased in volume and the low-salinity water between them decreased in volume during 2014-17, which caused significant positive salinity anomaly in the upper $400 \mathrm{~m}$ relative to the 
seasonal climatology derived from the Argo data during 2004-18 and persisted for more than three years. We used all the Argo float profiles from December 2001 to January 2018 and the gridded Argo datasets to analyze the ocean dynamics related to the prolonged highsalinity event. Our results suggested that the changes of the seasonally dependent eddies near the mouth of the Gulf of Oman were one of the most important factors for the high-salinity event during 2014-17.

The remainder of this paper is as follows. Section 2 describes the datasets and methods. The mean state and salinity anomalies in the northern Arabian Sea are presented in section 3. The dynamic processes associated with the high-salinity event and the salt budget analysis are described in section 4 . Section 5 shows an example of the high-salinity event captured by two Argo floats and discusses the possible processes affecting the event. Conclusions are given in section 6 .

\section{Data and methods}

\section{a. Data}

All the Argo profile data collected from December 2001 to January 2018 were used in this study to show the spatial and temporal variations of the water mass in the northern Arabian Sea. This dataset was obtained from the China Argo Real-time Data Center, which is originated from the Global Ocean Data Assimilation Experiment and the French Research Institute for Exploitation of the Sea. About 69 floats have been deployed in the northern Arabian Sea, and 12933 Argo profiles were collected in the region for the research period, of which 12854 profiles were used in this study after quality controls. The profile number dramatically increased after 2009 when the dataset satisfied the needs of our research on seasonal and interannual variations.

The Argo floats measure temperature and salinity from a designed depth of $2000 \mathrm{~m}$ up to a typical surface value at $5 \mathrm{~m}$ and record the data at vertical resolutions of $1-5 \mathrm{~m}$ in the upper ocean and coarser resolutions at depths. Based on Argo temperature and salinity fields, Scripps Institution of Oceanography creates a monthly gridded product for the global ocean at a $1^{\circ} \times 1^{\circ}$ grid (Roemmich and Gilson 2009). This product spans from 2004 to present and has 58 levels in vertical $2000 \mathrm{~m}$, with a vertical resolution of $10 \mathrm{~m}$ in the upper 200 and $20 \mathrm{~m}$ between 200 and $500 \mathrm{~m}$. This product provides a baseline of temperature and salinity data in the upper $2000 \mathrm{~m}$ ocean for the estimates of the interannual to decadal variability.

The monthly mean sea surface height anomaly (SSHA), surface current and wind, and freshwater flux [evaporation minus precipitation $(E-P)]$ data are used in this study. The SSHA is provided by AVISO (http:// www.aviso.altimetry.fr/), which is a multisatellite merged product that includes data from all of the available altimetry satellites. The dataset spans from 1993 to present with a $0.25^{\circ} \times 0.25^{\circ}$ grid. The Ocean Surface Current Analysis Real-Time (OSCAR) data are obtained from the National Oceanic and Atmospheric Administration (NOAA) (Bonjean and Lagerloef 2002), which spans from 1992 to present on a $1^{\circ} \times 1^{\circ}$ grid.

Four $E-P$ datasets that are obtained from five sources are used in this study, to illustrate the differences among the datasets and the possible errors of the freshwater flux in the northern Arabian Sea. The Global Precipitation Climatology Project (GPCP) version 2.2 (Adler et al. 2003; Huffman et al. 2009) monthly data and the objectively analyzed air-sea fluxes (OAFlux) monthly evaporation data (Yu and Weller 2007) are used to calculate $E-P$ for the period of 1979-17. They are the observed $E-P$ datasets and used for salinity budget analysis in this study. The precipitation data span from 1979 to present with a $2.5^{\circ} \times 2.5^{\circ}$ grid and are reconstructed into a $1^{\circ} \times 1^{\circ}$ grid using linear interpolation in this study. The evaporation spans from 1958 to present on a $1^{\circ} \times 1^{\circ}$ grid. The other three $E-P$ data are reanalysis datasets, which are obtained from the European Centre for Medium-Range Weather Forecasts (ECMWF) and the Physical Sciences Division (PSD) at NOAA. The monthly mean evaporation and total precipitation provided by the fifth generation ECMWF reanalysis (ERA5) [Copernicus Climate Change Service (C3S) 2017] span from 1979 to present with a $0.25^{\circ} \times 0.25^{\circ}$ grid. The monthly mean precipitation, sea surface temperature, and the latent heat net flux provided by the NCEP-NCAR Reanalysis 1 project (NCEP) (Kalnay et al. 1996) and the NCEPNCAR Reanalysis 2 project (NCEP2) (Kanamitsu et al. 2002) are used to calculate the $E-P$. First, $E$ is determined from latent heat flux $Q_{\mathrm{LH}}$ by the relation $E=$ $Q_{\mathrm{LH}} / \rho_{w} L_{e}$, where $\rho_{w}$ is the density of seawater, and $L_{e}=(2.501-0.00237 \times \mathrm{SST}) \times 1.0^{6}$ is the latent heat of vaporization $\left(\mathrm{J} \mathrm{kg}^{-1}\right)$. The NCEP datasets span from 1948 to present, and the NCEP2 datasets span from 1979 to present, both with a T62 Gaussian grid. The level-3.5 cross-calibrated multiplatform (CCMP) version 2.0 (Atlas et al. 2011; Wentz et al. 2015) monthly data are available from Remote Sensing Systems (RSS), which spans from 1988 to present with a resolution of $0.25^{\circ} \times 0.25^{\circ}$. We use data from the same period as that of Argo data in this study. The Indian Ocean dipole mode index (DMI) is calculated using the Reynolds OIv2 SST analysis (Reynolds et al. 2002), which is available at NOAA/ESRL. 


\section{b. Methods}

The $\mathrm{P}$-vector inverse method is used to derive the fourdimensional velocities on the isopycnic surfaces based on Argo product. This method was first proposed in Chu (1995) and then was tested to be reliable in many studies (Chu and Li 2000; Chu et al. 2002; Li et al. 2018). The $\mathrm{P}$-vector method calculates the absolute geostrophic circulations on the isopycnic surfaces by two steps.

The first step is to determine a unit tangential vector $\mathbf{P}$ by assuming conservation of potential vorticity and density, which can be defined as

$$
\mathbf{P}=\frac{1}{|\nabla q|}\left(\frac{\partial q}{\partial y} i-\frac{\partial q}{\partial y} j\right)
$$

where $q=f g(\partial p / \partial \rho)^{-1}$ is the potential vorticity in the isopycnic coordinate system, $f$ is the Coriolis parameter, $g$ is the gravitational constant, $p$ is the pressure, and $\rho$ is the potential density.

The second step is to determine the absolute geostrophy by

$$
V=\gamma(x, y, \rho) \mathbf{P},
$$

where $\gamma$ is the speed, which can be determined by applying the thermal wind relation to any two different isopycnic levels. The thermal wind relation is written by

$$
\frac{\partial u}{\partial \rho}=\frac{1}{f \rho^{2}} \frac{\partial p}{\partial y}, \quad \frac{\partial v}{\partial \rho}=-\frac{1}{f \rho^{2}} \frac{\partial p}{\partial x},
$$

where $u, v$ are zonal and meridional velocities. Readers are referred to Chu (1995) and Chu and $\mathrm{Li}$ (2000) for more details about the P-vector inverse method.

Further, the salinity budget is analyzed for the geographical domain in the Arabian Sea north of $20^{\circ} \mathrm{N}$, and bounded by the Omani coast and $60^{\circ} \mathrm{E}$ in the west to the west Indian coast in the east. We choose $60^{\circ} \mathrm{E}$ as the western boundary to assess the contribution of the highsalinity spreading from the Gulf of Oman to the northern Arabian Sea. We choose $\sigma_{0}=26.8 \mathrm{~kg} \mathrm{~m}^{-3}$ as the bottom boundary and calculate the salinity budget between the surface and the bottom isopycnic layer so as to include all the transport associated with the high-salinity PGW. The salinity budget is formulated as

$$
\begin{aligned}
\frac{\partial[S]}{\partial \mathrm{t}}= & \operatorname{Adv}+F_{s}+\text { Res, } \\
\operatorname{Adv}= & \frac{1}{V}\left(\iint_{60^{\circ} \mathrm{E}} u(S-[S]) d y d z\right. \\
& \left.+\iint_{20^{\circ} \mathrm{N}} v(S-[S]) d x d z\right),
\end{aligned}
$$

$$
\begin{aligned}
& F_{s}=\frac{[S]}{V} \iint_{A}(E-P) d A, \quad \text { and } \\
& {[S]=\frac{1}{V} \iiint_{V} S d V .}
\end{aligned}
$$

where $S$ is the salinity on the isopycnic layer; Adv is the total advection, including the zonal advection across the transect at $60^{\circ} \mathrm{E}$ and the meridional advection across the transect at $20^{\circ} \mathrm{N} ; u, v$ are, respectively, the zonal and meridional geostrophic currents on the isopycnic layer calculated by the P-vector inverse method; $F_{s}$ is the freshwater term; $E$ and $P$ are, respectively, the evaporation and precipitation; $V$ and $A$ are, respectively, the volume and the surface area of the domain; $z$ is the thickness of the isopycnic layer; and $[S]$ is the timevariable but space-averaged salinity within the control volume. In this study, the residual term includes the errors caused by freshwater flux, the mixing across the bottom boundary layer and other high-order disturbance, plus the advection caused by the coastal currents, since the Argo observations do not cover the near-coastal regions.

\section{The mean and variability of the salinity in the northern Arabian Sea}

\section{a. Annual mean and seasonal variability}

The sea surface salinity (SSS) pattern in the tropical Indian Ocean shows a significant contrast from west to east and from south to north. This pattern is dominated by $E-P$ on the annual mean scale (Fig. 1a). The excess of evaporation over precipitation in the Arabian Sea and the subtropical southern Indian Ocean leads to the formation of the high-salinity water mass in the west and south, while the excessive precipitation and river runoffs in the Bay of Bengal and the eastern Indian Ocean lead to the low-SSS water in the east (Fig. 1a). Meanwhile, the low-salinity water transported by the Indonesian Throughflow (ITF) joins the westward South Equatorial Current, forming a low-SSS tongue along the path near $12^{\circ} \mathrm{S}$ (Gordon 2005; Sprintall et al. 2009).

The SSS in the northern Arabian Sea (north of $19^{\circ} \mathrm{N}$ ), where ASHSW forms, shows the highest values in the Indian Ocean. The strong evaporation during winter directly leads to the formations of the ASHSW in the northern Arabian Sea and the Gulf of Oman (Prasad and Ikeda 2002a). However, the SSS shows a semiannual cycle in the northern Arabian Sea, with the highest peak occurring in May and the secondary peak in November, which is different from the annual cycle of the $E-P$ (Fig. 1b). Previous studies suggested that the ocean advection might modulate the seasonality of the SSS in the 
(a) salinity
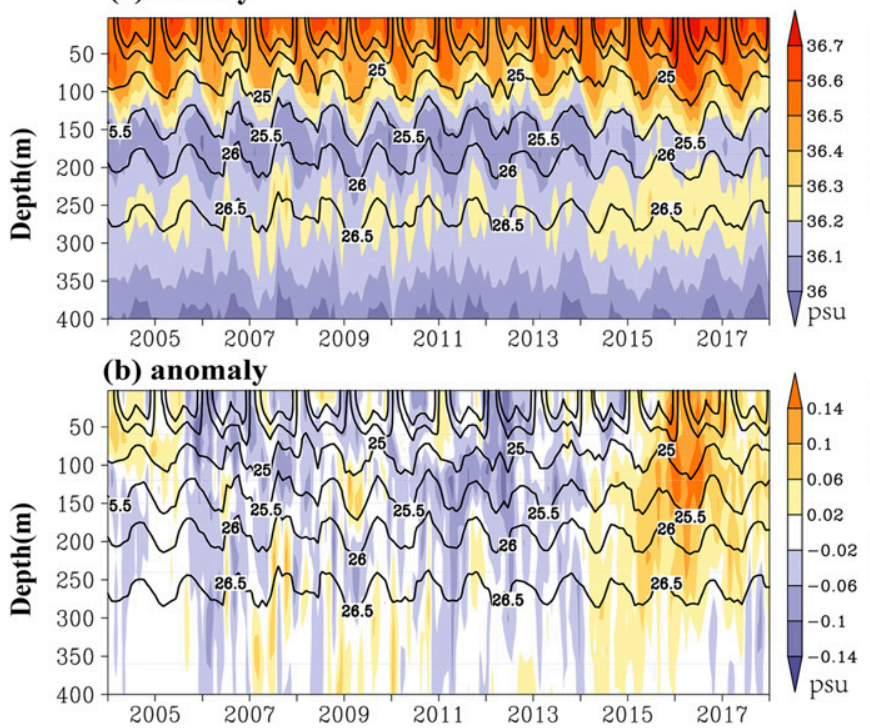

(c) E-P and volume anomalies

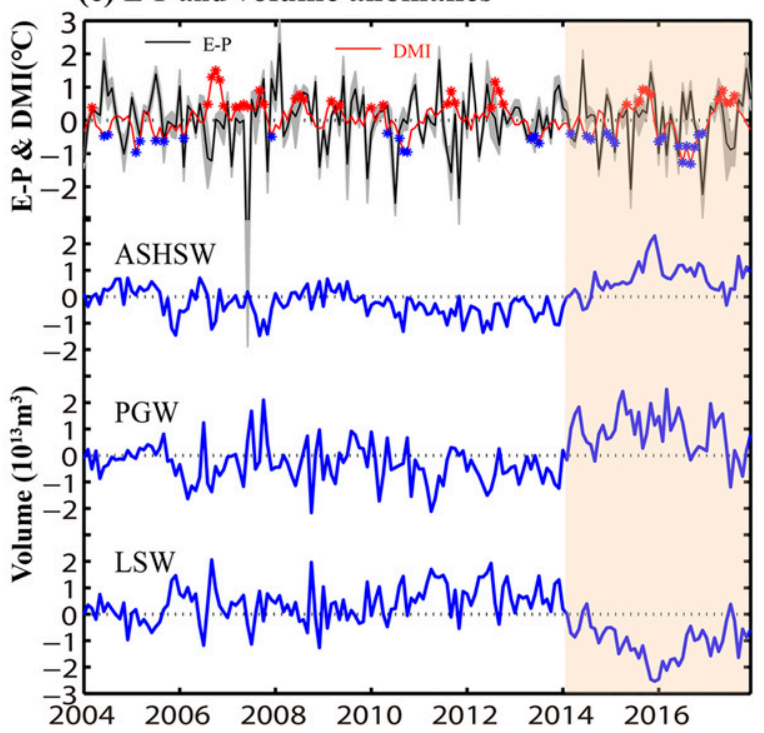

FIG. 2. Variations of the regional mean salinity and the anomaly with depth, and the surface $E-P$ and the volume anomalies of three water masses in the northern Arabian Sea. (a) Salinity (shaded; psu), (b) anomaly (shaded; psu), and (c) ensemble mean (black curve; mm month ${ }^{-1}$ ) and the standard deviation (gray shading) of the standardized $E-P$ obtained from five sources, superimposed on the index of Indian Ocean dipole mode (DMI; red curve; ${ }^{\circ} \mathrm{C}$ ), and the volume anomalies (blue curves; $10^{13} \mathrm{~m}^{3}$ ) of high-salinity water $(S \geq 36.2$ psu) in the surface (ASHSW) and in the intermediate layers (PGW) and the low-salinity water (LSW; $S \leq 36.1 \mathrm{psu}$ ) in the subsurface layers. The regional mean $\sigma_{0}$ (black curves; $\mathrm{kg} \mathrm{m}^{-3}$ ) are superimposed in (a) and (b). Values of DMI in (c) larger than 0.8 times the standard deviation are marked with asterisks.

region (Joseph and Freeland 2005; Morrison 1997). The mean circulation in the northern Indian Ocean changes from clockwise flowing during summer to anticlockwise during winter caused by the monsoon forcing (Schott and McCreary 2001), which carries the ASHSW southward and brings the low-salinity water into the northern Arabian Sea twice a year (Jensen 2003).

The PGW is manifested as a salinity maximum in the intermediate layer between 200 and $350 \mathrm{~m}$ or $\sigma_{0}=26.1-$ $26.7 \mathrm{~kg} \mathrm{~m}^{-3}$ (Fig. 2a). Low-salinity water appears between the surface ASHSW and the intermediate PGW, which is originated from the southern Indian Ocean or Bay of Bengal. Both the salinity of the intermediate PGW and the subsurface low-salinity water show strong seasonal cycles in the northern Arabian Sea (Fig. 2a). The monsoon circulation and associated eddies are crucial to the spreading of the PGW and the intrusion of the subsurface low-salinity water in the northern Arabian Sea (L'Hégaret et al. 2016, 2013).

\section{b. The high-salinity event and its seasonality}

Intense interannual variability of the water salinity occurred in the northern Arabian Sea compared to the regional air-sea freshwater flux variations (Fig. 2). Obvious positive salinity anomalies $(>0.02 \mathrm{psu})$ appeared in the upper $400 \mathrm{~m}$ with the regional mean value increased by more than 0.14 psu at its peak during 2014-17 (Fig. 2b), while the freshwater fluxes obtained from five sources (OAFlux and GPCP, ERA5, NCEP, NCEP2) changed little before and after 2014 (Fig. 2c). Considering the changes of the typical water masses in the northern Arabian Sea, a prolonged high-salinity event was identified during 2014-17, lasting for more than 3 years, when both the volumes of the surface ASHSW and the intermediate PGW increased, with the volume of the lowsalinity water between them reduced (Fig. 2c).

From Argo $\theta / S$ profiles collected between December 2001 and January 2018 in the northern Arabian Sea, the ASHSW showed as the surface salinity maximum with the highest salinity larger than $37 \mathrm{psu}$, and the PGW showed as the intermediate salinity maximum with the highest salinity larger than 38 psu for $\sigma_{0}=26.1-$ $26.7 \mathrm{~kg} \mathrm{~m}^{-3}$ in the northern Arabian Sea (Fig. 3). Between ASHSW and PGW, there was a low-salinity water at the subsurface (Figs. 3a,b). Some surface water with salinity lower than 35 psu can be seen in the diagrams, which indicated the water affected by the regional rainfall (L'Hégaret et al. 2015).

Using all the profiles shown in Fig. 3, we plotted the map of the salinity by applying a least squares optimal interpolation following (Wang et al. 2013). Here, based on 17-yr Argo profiles collected since 2001, the results showed that the salinity maxima in the surface and the minima in the subsurface can be used to illustrate the advection of the ASHSW and the low salinity. Note that Argo profiles covered most of the northern Arabian Sea, 
(a) December 2001- December 2013

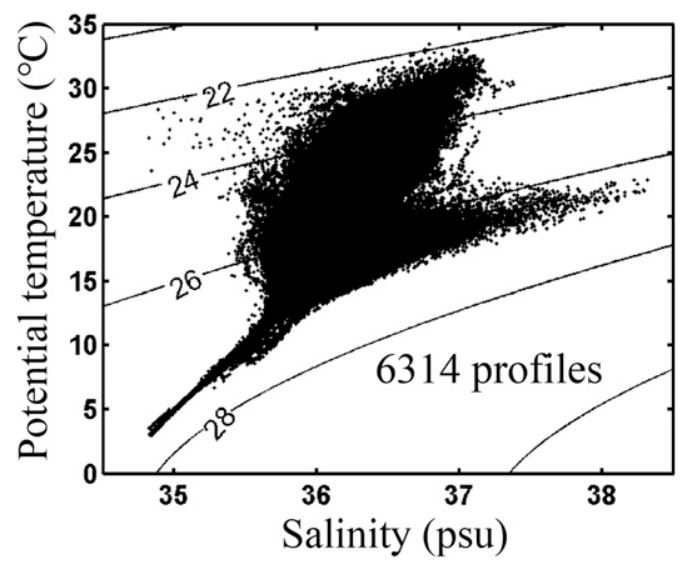

(b) January 2014 - January 2018

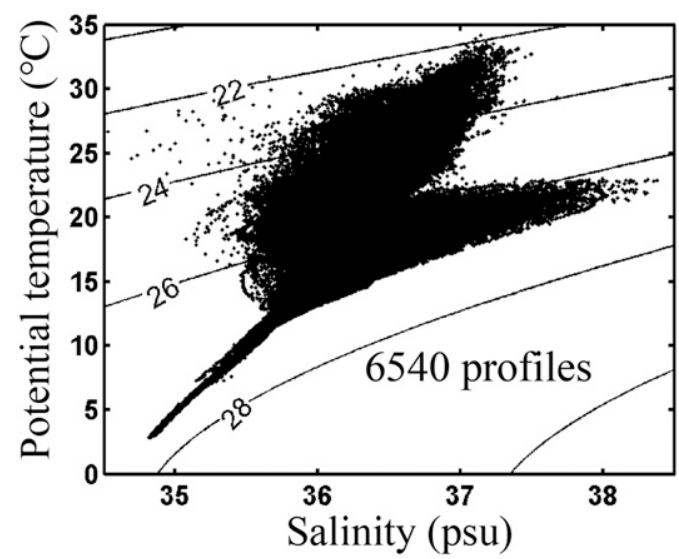

FIG. 3. Potential temperature-salinity $(\theta-S)$ diagrams in the northern Arabian Sea and the Gulf of Oman $\left(56^{\circ}-68^{\circ} \mathrm{E}, 19^{\circ}-26^{\circ} \mathrm{N}\right)$. (a) December 2001-December 2013 and (b) January 2014-January 2018.

especially the northeastern region (Fig. 4b). This is one of the source regions of ASHSW which had not been covered previously (Wang et al. 2013). In the Gulf of Oman and the northern Arabian Sea, the monthly census of the Argo profiles exceeded 50 after 2009, which was equivalent to more than one profile at a $1^{\circ} \times 1^{\circ}$ grid (Fig. 4d). The density of Argo profiles in the Gulf of Oman was higher than that in most regions of the northern Arabian Sea, which was sufficient to detect the high-salinity advection associated with the eddies. (a) S maxima in $0-150 \mathrm{~m}$

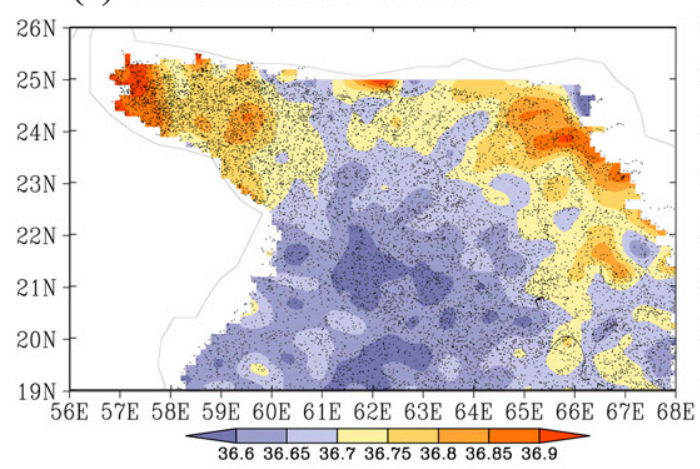

(b) S maxima in $150-350 \mathrm{~m}$

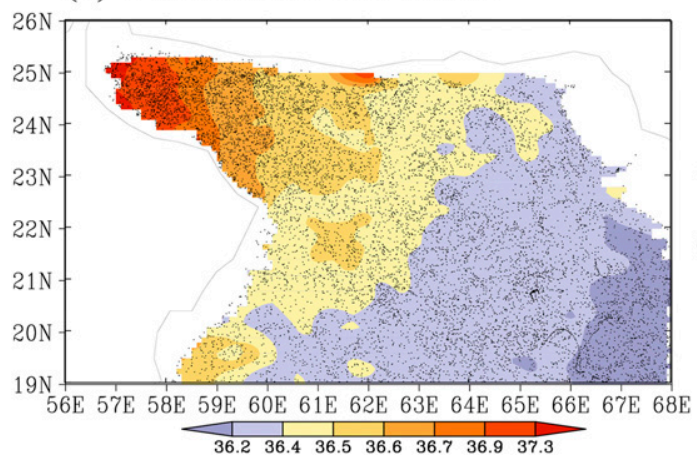

(c) S minima in 0-200 m

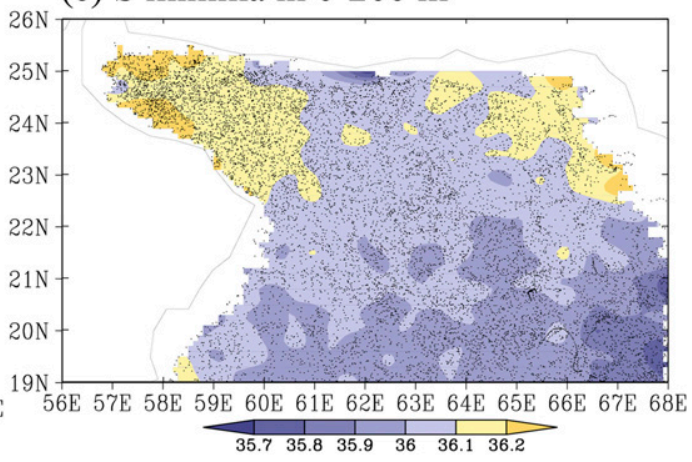

(d) profiles

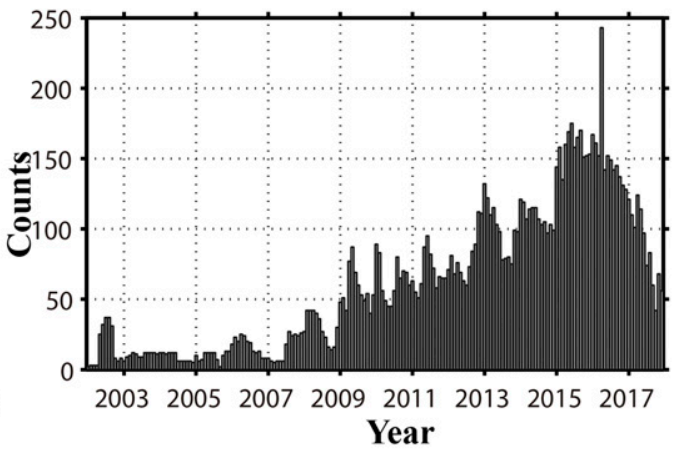

FIG. 4. Vertical salinity maxima and minima (psu) obtained from Argo profiles during 2001-17 and the distribution and numbers of the profiles in the northern Arabian Sea and the Gulf of Oman. (a) Salinity maxima in 0-150 m, (b) salinity maxima in $150-350 \mathrm{~m}$, (c) salinity minima in 0-200 m, and (d) monthly census of profiles. Black dots in (a)-(c) showed the geographical distribution of ARGO hydrographic profiles. 
(a) $\mathrm{S}$ maximum in $0-150 \mathrm{~m}$

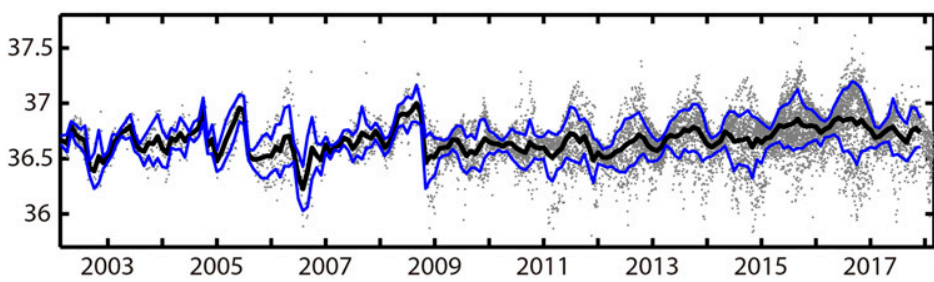

(b) $\mathrm{S}$ maximum in $150-350 \mathrm{~m}$

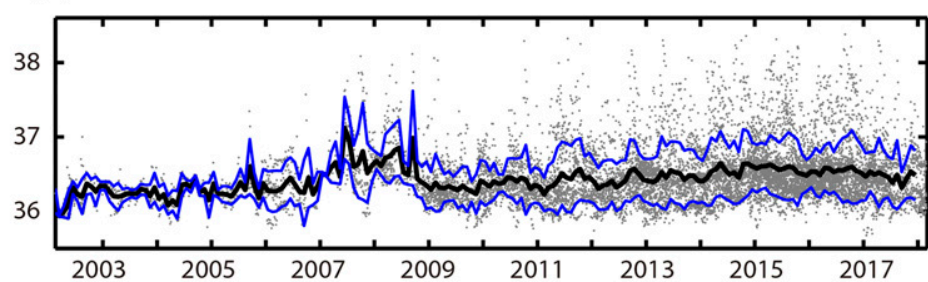

(c) $\mathrm{S}$ minimum in $0-200 \mathrm{~m}$

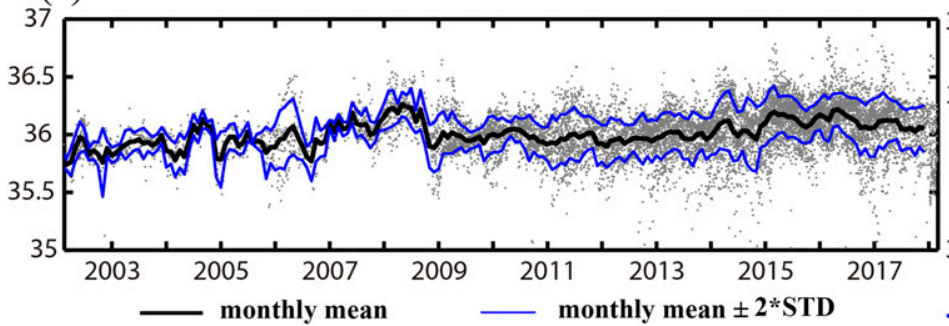

(d) seasonal cycle

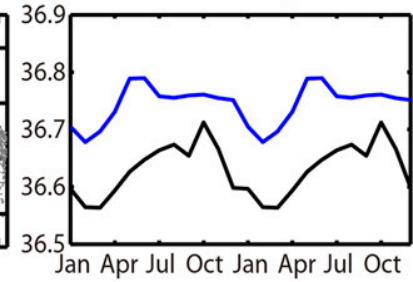

(e) seasonal cycle

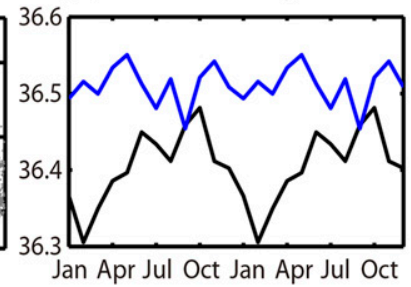

(f) seasonal cycle

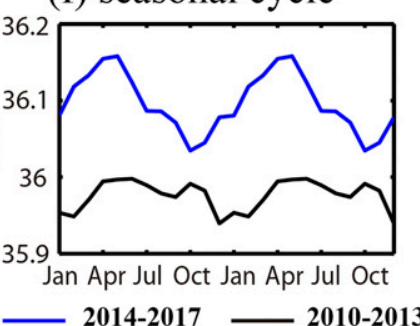

FIG. 5. Temporal variability of the vertical salinity maxima and minima (psu) in the (left) Argo profiles (gray dots) and (right) seasonal cycles (curves) in the northern Arabian Sea and the Gulf of Oman. (a),(d) Salinity maxima in $0-150 \mathrm{~m}$, (b),(e) salinity maxima in $150-350 \mathrm{~m}$, and (c),(f) salinity minima in 0-200 $\mathrm{m}$. Bold dark and blue curves in (a)-(c) are monthly mean values and the ranges of $2 \times$ standard deviations, respectively. Bold blue and dark curves in (d)-(f) are seasonal cycles of monthly mean during 2014-17 and during 2010-13, respectively.

In the surface layer, the ASHSW originates in the western Gulf of Oman and the northeastern Arabian Sea. These two regions are characterized by an excess of evaporation over precipitation and the shallow water mass which favored the formation of the highsalinity water (Fig. 4a). The surface high-salinity water in the Gulf of Oman is saltier than that in the northeastern region. This implies that the spreading of the surface high-salinity water from the Gulf of Oman can also cause an increase of salinity in the northern Arabian Sea, although the regional freshwater flux has no significant change (Fig. 2a). In the subsurface layer, the relatively low-salinity water spreads northward to the northern coastal region through the central northern Arabian Sea (Fig. 4c). Besides, there are many fragments of the high- and low-salinity signals distributed in the layers of three water masses, which implies the influence of eddies on the spreading of the three water masses (Carton et al. 2012; L'Hégaret et al. 2013).
The seasonal cycles of the salinities in all three layers were more credible after 2009 since there were sufficient Argo observations in the northern Arabian Sea and the Gulf of Oman (Fig. 5). Thus, in order to explain the drivers for the prolonged high-salinity event during 2014-17, we take the conditions in $2010-13$ as the background climatology.

The salinity in the three layers in 2010-13 showed similar seasonal variability to the regional mean SSS, which indicated that the processes that impacted the surface may also impact the subsurface and the intermediate layer (Figs. 5d-f and 1b). Both the values of monthly mean salinity and the numbers of the values higher than twice the standard deviation dramatically increased during 2014-17 (Figs. 5a-c). The mean values of the salinity seasonal cycle in the three layers during 2014-17 was higher than that during $2010-13$ by 0.1 psu in most months; The largest differences occurred in April-July and NovemberFebruary. The analysis based on Argo profiles showed 
that a prolonged high-salinity event may indeed have occurred during 2014-17, and it had a strong seasonal dependence.

\section{Development of the high-salinity event}

The mouth of the Gulf of Oman is a key chokepoint for the high-salinity advection to the northern Arabian Sea. To understand the processes that caused the development of the high-salinity event, we first analyzed the high-salinity spreading across the transect at $60^{\circ} \mathrm{E}$ near the mouth of the Gulf of Oman.

\section{a. Surface high-salinity water spreading}

The surface ASHSW (salinity $>36.4 \mathrm{psu}$ ) showed a strong seasonal cycle on the transect at $60^{\circ} \mathrm{E}$. It was restricted to a near-surface layer from July to November, deepened during winter, when convective mixing occurred due to heat and freshwater loss, and then shoaled after spring (Fig. 6). During winter for 2010-13, the mixed layer depth deepened to $100 \mathrm{~m}$ in February (Fig. 6a). Then some of the ASHSW subducted into the depth below the mixed layer, reached $140 \mathrm{~m}$ in March (Fig. 6a). The salinity of the surface ASHSW during 2014-17 was higher than that during 2010-13, and more ASHSW subducted into the depth below the mixed layer, reached $150 \mathrm{~m}$ at the deepest (Fig. 6b). The difference of the salinity on the transect between the periods of 2014-17 and 2010-13 showed that the strengthened advection of the surface ASHSW occurred in April-July and November-February, which was consistent with a seasonal increase of the regional high salinity (Fig. 5d).

Further, the surface salinity in April-July and November-February and the 2-month leading eddy processes during 2010-13 and 2014-17 were shown in Fig. 7. In November-January for 2010-13, the surface ASHSW (salinity $>36.4 \mathrm{psu}$ ) in the Gulf of Oman extended through the mouth of the Gulf to the northern Arabian Sea along the southern coast caused by a northwest-southeast-oriented oval cyclonic eddy across the mouth of the Gulf (Fig. 7a). The southern flank of the eddy advected the high-salinity water to the northern Arabian Sea along the Omani coast. Meanwhile, the eastern flank of the eddy advected the relatively lowsalinity water $(S<36.4)$ northward. The other highsalinity center in the northeastern Arabian Sea didn't show any significant spreading since the northeast monsoon current flowed northward during this season (Schott and Fischer 2000; Stramma et al. 2002).

The salinity near the mouth of the Gulf of Oman during November-January for 2014-17 was higher than that during November-January for 2010-13 (Fig. 7b).

\section{(a) $2010-2013$}

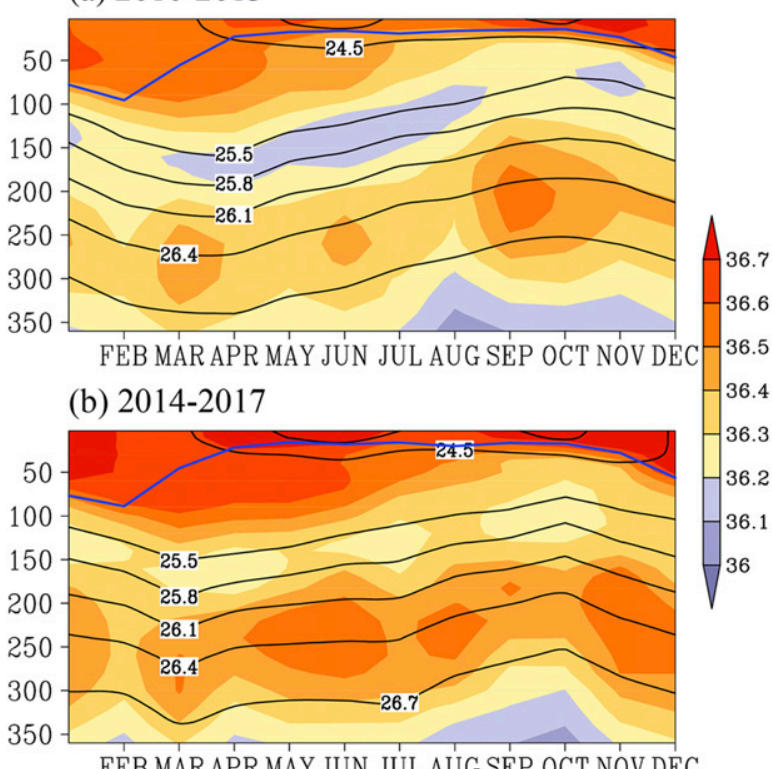

FEB MAR APR MAY JUN JUL AUG SEP OCT NOV DEC

\section{(c) difference}

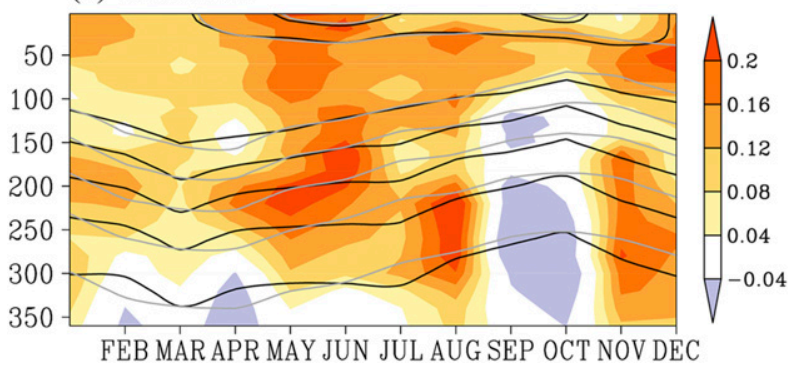

FIG. 6. Time-depth diagrams of the mean salinity (shaded; psu) and $\sigma_{0}$ (contours; $\mathrm{kg} \mathrm{m}^{-3}$ ) on the transect at the mouth of the Gulf of Oman $\left(60^{\circ} \mathrm{E}, 22^{\circ}-24^{\circ} \mathrm{N}\right)$ before and during the prolonged highsalinity event and their difference: (a) 2010-13 and (b) 2014-17. (c) The differences between the latter and the former. The mean $\sigma_{0}$ values for 2014-17 (black curves) and 2010-13 (gray curves) are superimposed in (c). The blue lines in (a) and (b) are the mixed layer depths.

The increase of the salinity was highly related to the westward shifted and weakened cyclonic eddy near the mouth of the Gulf of Oman, as compared to that during 2010-13. The center of the eddy shifted to the west of $60^{\circ} \mathrm{E}$ and the western flank of the eddy stretched to the western part of the Gulf of Oman, which favored the advection of the higher salinity ASHSW from the western part of the Gulf of Oman to the northern Arabian Sea (Fig. 7b). The weakened cyclonic eddy caused an anomalous southward flow on the eastern flank of the eddy, which led to less northward advection of the relatively low-salinity water, further contributing to the salinity increase (Fig. 7c).

In May-July for 2011-13, the surface ASHSW in the Gulf of Oman spread off the west coast of Oman near 
$\operatorname{SSS}(\mathrm{NDJ}) / \mathrm{SSHa} \&$ current(SON)

(a) 2010-2013

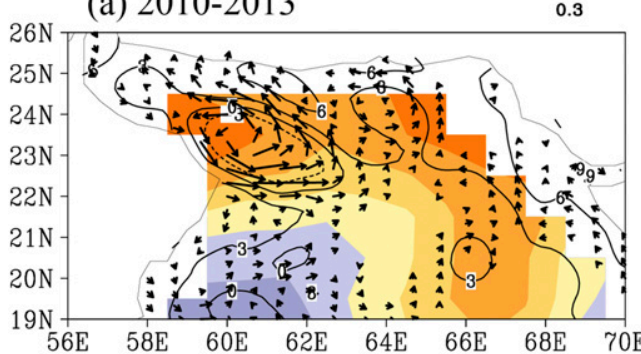

(b) $2014-2017$

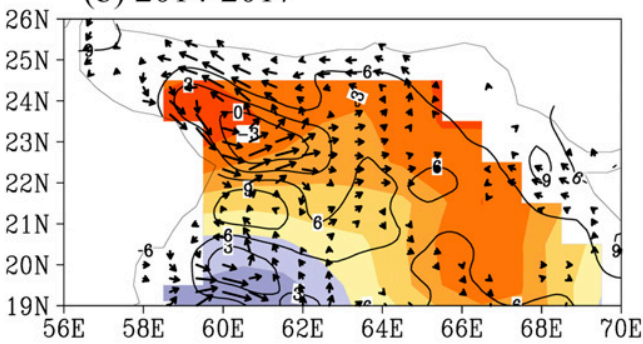

(c) difference

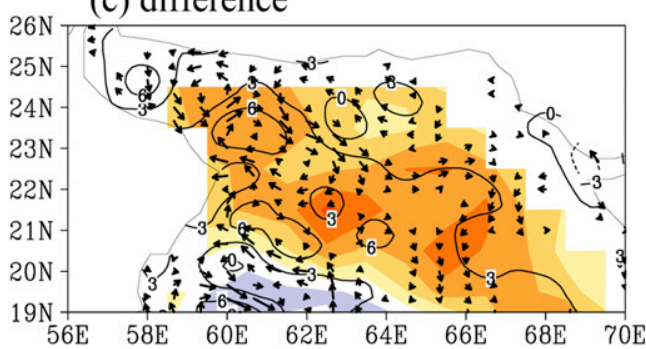

SSS(MJJ)/SSHa\&current(MAM)

(d) 2011-2013

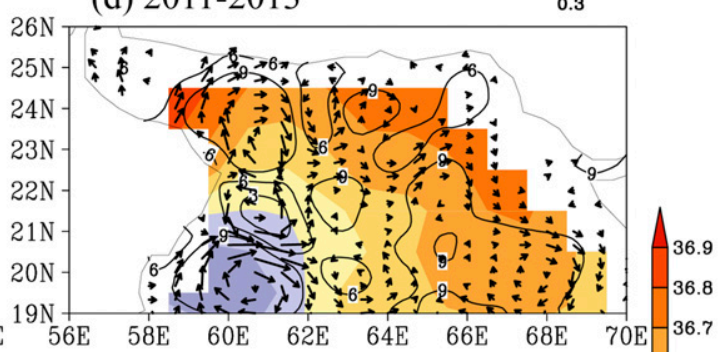

(e) $2015-2017$

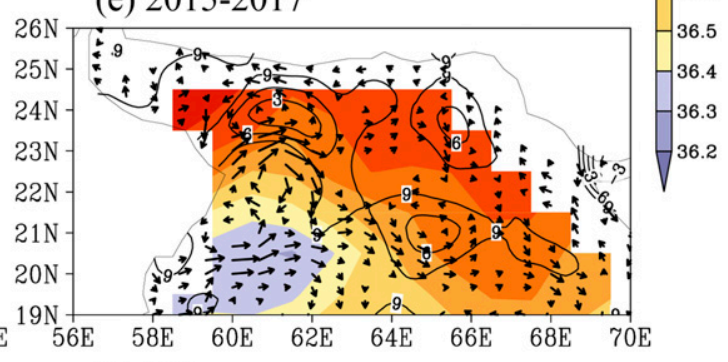

(f) difference

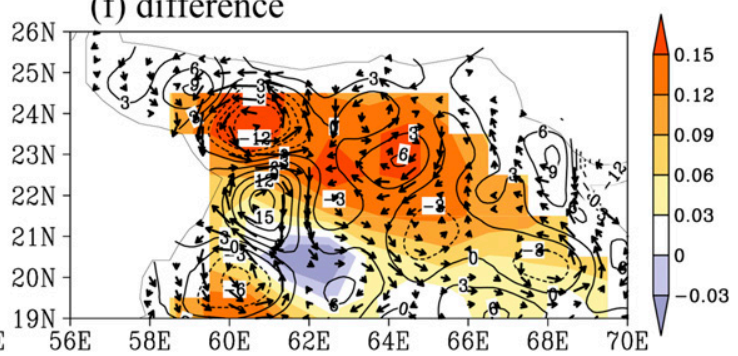

FIG. 7. Seasonal mean sea surface salinity (SSS; shaded; psu), AVISO SSH anomaly (contours; $\mathrm{cm}$ ) and OSCAR currents (vectors; $\mathrm{m} \mathrm{s}^{-1}$ ) in the northern Arabian Sea and the Gulf of Oman before and during the prolonged highsalinity event and their differences. (a),(b) November to the following January mean sea surface salinity and the 2-month lead SSH anomaly and currents during 2010-13 and 2014-17, respectively, (d),(e) May-July mean sea surface salinity and the 2-month lead SSH anomaly and currents during 2011-13 and 2015-17, respectively, and (c),(f) the differences between the latter period and the former.

Ras Al Hamra into the central and northern Gulf and then was advected into the northern Arabian Sea by an anticyclonic eddy near the mouth of the Gulf of Oman (Fig. 7d). The northern flank of anticyclone formed the eastward Ras Al Hadd Jet, favoring the spreading of the high-salinity water and the southern flank advected the relatively low salinity into the south of the Gulf. The low-salinity water upwelled to the surface near the south Omani coast (Fischer et al. 2002). In May-July, an eddy dipole off the south Omani coast advected this upwelled low-salinity water northward, then fed into the anticyclonic eddy near the mouth of the Gulf of Oman (Fig. 7d). In the eastern part, the high-salinity water spread southward by the southward flowing currents during the season (Fig. 7d).

In the same season for the high-salinity event in 201517 , the salinity dramatically increased in most regions of the northern Arabian Sea caused by an anomalous eddy dipole with a cyclone in the north and an anticyclone in the south near the mouth of Gulf of Oman, as compared to that during 2011-13 (Figs. 7e,f). This eddy dipole strengthened the Ras Al Hadd Jet and its high-salinity advection into the northern Arabian Sea (Fig. 7e). Along the south Omani coast, the anticyclone and its northward low-salinity advection weakened during 2015-17 than that during 2011-13, which also led to the increase of salinity in the northern Arabian Sea (Fig. 7f).

\section{b. Intermediate $P G W$ spreading}

On the transect of $60^{\circ} \mathrm{E}$ near the mouth of the Gulf of Oman, the intermediate PGW spread through the mouth of the Gulf of Oman during three peak periods: February-April, May-July, and August-November (Fig. 6a). The last one was much stronger than the 
$\mathrm{S}(\mathrm{NDJ}) /$ depth\&current(SON)

(a) 2010-2013 $\overrightarrow{0.02}$

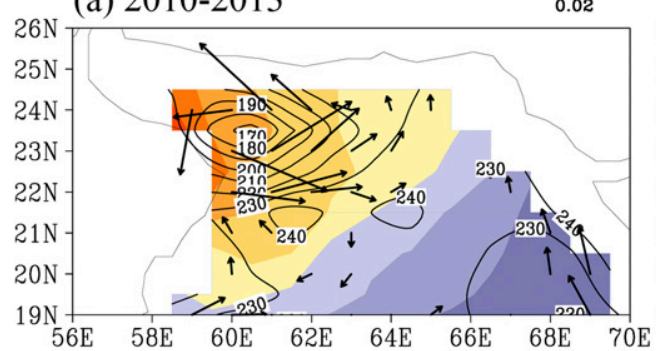

(b) 2014-2017

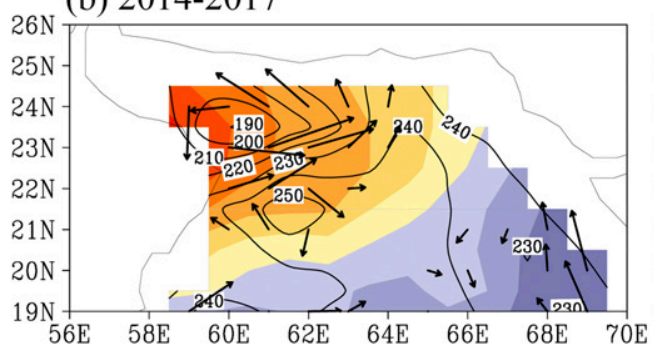

(c) difference

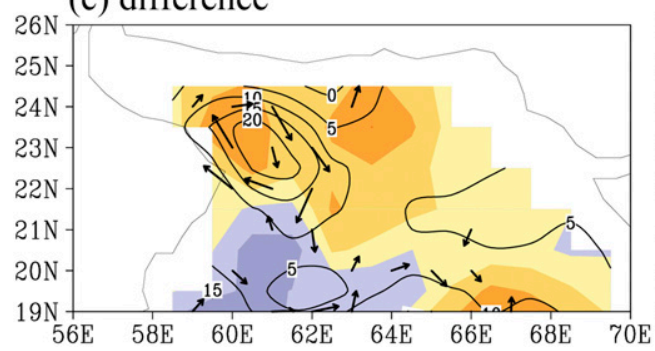

$\mathrm{S}(\mathrm{MJJ}) /$ depth\&current(MAM)

(d) 2011-2013 $\overrightarrow{0.02}$

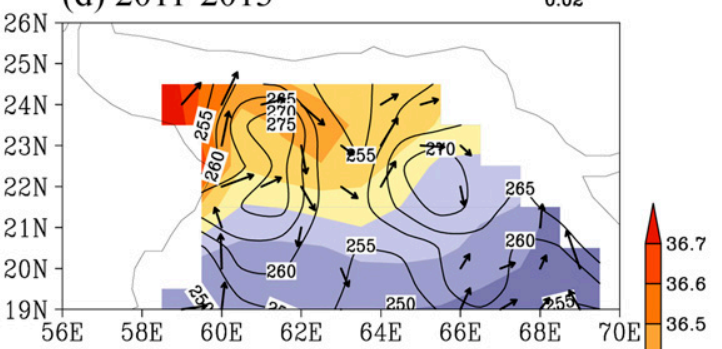

(e) $2015-2017$

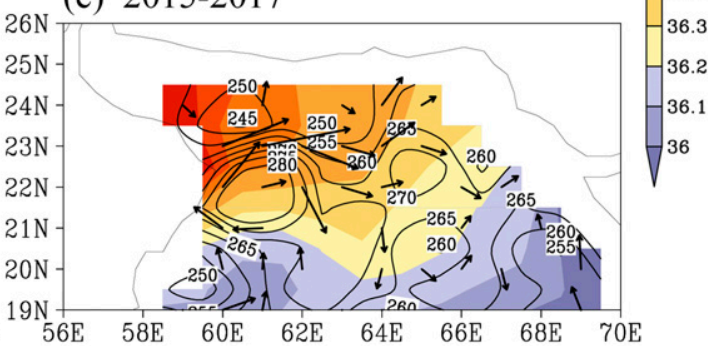

(f) difference

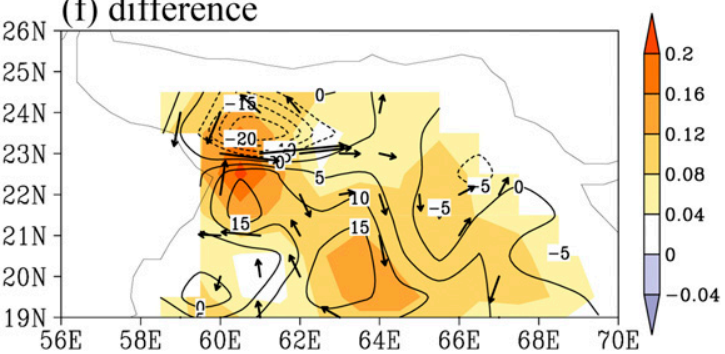

FIG. 8. As in Fig. 7, but for seasonal mean salinity (shaded; psu), layer depth (contours; m) and geostrophic currents (vectors; $\mathrm{m} \mathrm{s}^{-1}$ ) in the layers between $\sigma_{0}=26.3$ and $26.6 \mathrm{~kg} \mathrm{~m}^{-3}$.

previous two, indicating that more PGW spread to the northern Arabian Sea during boreal fall. The seasonal cycle of the PGW on the transect showed some phase shift during the high-salinity event in 2014-17 (Fig. 6b), and the salinity increased along the annual cycle with the most significant positive salinity anomaly occurring in May-July and November-January (Fig. 6c).

During November-January in 2010-13, consistent with the surface, the high-salinity water in the intermediate layers $\left(\sigma_{0}=26.3-26.6 \mathrm{~kg} \mathrm{~m}^{-3}\right)$ extended to the northern Arabian Sea along the Omani coast caused by the cyclonic eddy centered near the mouth of the Gulf of Oman (Fig. 8a). However, the conditions in NovemberJanuary during the high-salinity event in 2014-17 showed some differences compared to that during 201013: the water was saltier and the cyclonic eddy was weaker and westward shifted (Fig. 8b). The salter PGW in the western part of the Gulf of Oman was advected by the southern flank of the cyclonic eddy to the northern Arabian Sea, causing significant positive salinity anomaly
(Fig. 8c). The eddy structures and their high-salinity advection were much clearer in the intermediate layer than that in the surface layer (Figs. 7 and 8) since the surface layer was directly affected by the high-frequency atmosphere forcing.

The spreading of the PGW took its northern path during the spring and summer monsoon, which was caused by the Ras Al Hadd Jet (Böhm et al. 1999; Prasad et al. 2001). In May-July for 2011-13, the Ras Al Hadd Jet in the intermediate layer was a part of the anticyclonic eddy near the mouth of the Gulf of Oman (Fig. 8d). A meridional oval anticyclonic eddy occupied over the western part of the northern Arabian Sea, which caused the northward advection of the lowsalinity water along the western coast and the eastward spreading of the high-salinity PGW to the central northern Arabian Sea over the north of $24^{\circ} \mathrm{N}$ (Fig. 8d).

In the same season during the high-salinity event in 2015-17, an eddy dipole near the mouth of the Gulf of Oman (Fig. 8e), instead of the developed one anticyclonic 
circulation in the normal condition (Fig. 8d), contributed to the spreading of the PGW to the northern Arabian Sea. The strengthened Ras al Hadd Jet advected more PGW into the northern Arabian Sea, causing a significant increase of the salinity along a narrow path of the Jet between $22^{\circ}$ and $23^{\circ} \mathrm{N}$ (Fig. 8e). Besides, the influence of the weakened coastal summer monsoonal current and its reduced low-salinity advection also appeared in the intermediate layer (Fig. 8e).

Both in the surface and intermediate layers, the highsalinity water spreading from the Gulf of Oman to the northern Arabian Sea were strengthened by the change of the eddies near the mouth of the Gulf of Oman, including the weakened and west shifted cyclonic eddy during fall and early winter and an eddy dipole during spring and early summer, which might be an important reason for the developing of the prolonged high-salinity event in 2014-17.

\section{c. Subsurface low-salinity water intrusion}

The northward advection of the low-salinity water is another important factor influencing the salt balance in the northern Arabian Sea. On the transect at $20^{\circ} \mathrm{N}$, the subsurface low-salinity water (salinity $<36.1 \mathrm{psu}$ ) appeared in the layers of $\sigma_{0}=25.5-26.0 \mathrm{~kg} \mathrm{~m}^{-3}$ nearly all the year round with two weak periods in May-July and September-November when the surface ASHSW and the intermediate PGW spread southward through the transect during the normal condition in 2010-13 (Fig. 9a).

The thickness of low-salinity water (salinity $<36.1 \mathrm{psu}$ ) in the subsurface layer on the transect decreased dramatically during the high-salinity event during 2014-17, especially in the phase-locked season with the highsalinity southward extension (Fig. 9b), which caused the significant positive salinity difference in the subsurface layer between 2014-17 and 2010-13 (Fig. 9c). Note that, the significant anomalous low-salinity water advection across the transect of $20^{\circ} \mathrm{N}$ occurred during April-June and October-December.

During October-December in 2010-12, the lowsalinity water (salinity $<36.1 \mathrm{psu}$ ) in the layers of $\sigma_{0}=$ $25.5-26.0 \mathrm{~kg} \mathrm{~m}^{-3}$ intruded northward to the northern coastal region of the Arabian Sea (Fig. 10a). This lowsalinity water may be transported by eddies from the upwelling region near the Omani coast or carried by the West Indian Coastal Current from the equator (Fig. 10a). In the same season during the high-salinity event in 2014-16, the salinity near the northern coastal region was about 0.1 psu higher than that during 2010-12, and the low-salinity water (salinity $<36.1 \mathrm{psu}$ ) just occupied the region south of $20^{\circ} \mathrm{N}$ (Fig. 10b). The West Indian Coastal Current was weaker than that during 2010-12, causing weakened northward low-salinity

\section{(a) $2010-2013$}

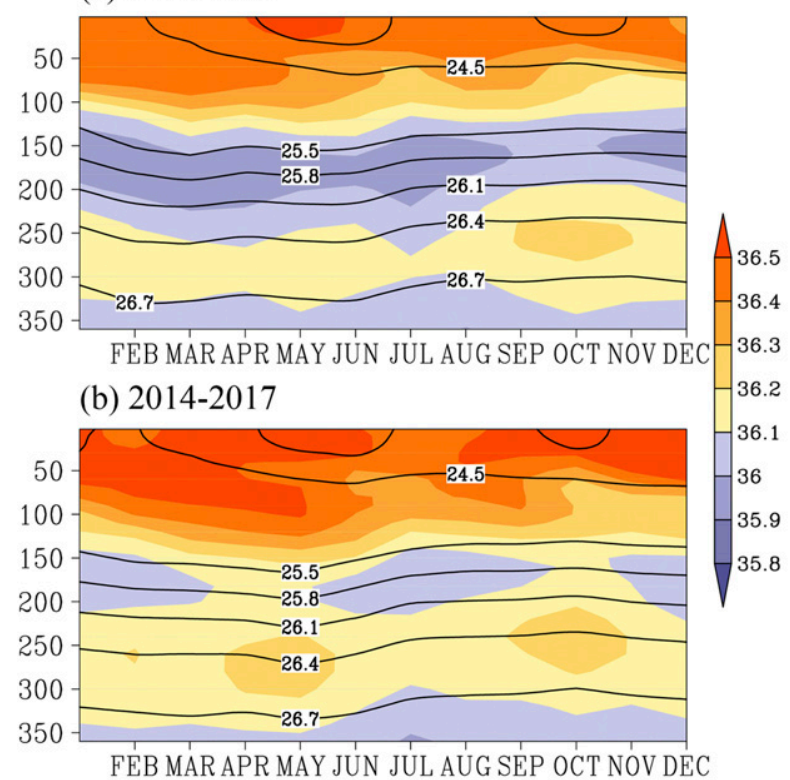

(c) difference

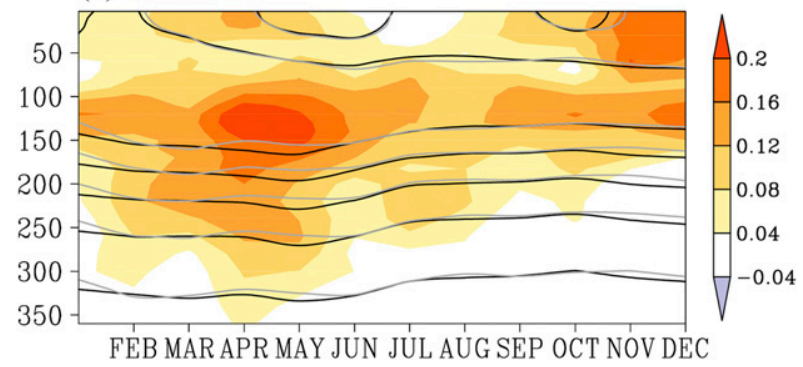

FIG. 9. As in Fig. 6, but in the transect at the south of the northern Arabian Sea $\left(58^{\circ}-68^{\circ} \mathrm{E}, 20^{\circ} \mathrm{N}\right)$.

advection and a dramatic salinity increase all over the northern Arabian Sea.

During April-June in 2011-13, the low-salinity water $(S<36.1 \mathrm{psu})$ spread to nearly $22^{\circ} \mathrm{N}$ over the whole basin by the northward currents, especially the strong northward coastal currents near the Oman (Fig. 10d). The low-salinity water during April-June in 2015-17 was confined within the region south of $20^{\circ} \mathrm{N}$ caused by the weakened northward currents, as compared to that during April-June in 2011-13 (Fig. 10e). The weakened northward coastal currents along the Omani coast and its low-salinity water advection caused a significant increase of salinity all over the northern Arabian Sea during April-June in 2015-17, as compared to that during 2010-13 (Fig. 10f).

\section{d. Changes in salt balance}

The mean tendency of the average salinity within the control volume was very small during 2010-13, although the seasonal and interannual variability was intense 
$\mathrm{S}(\mathrm{OND} /$ depth\&current(ASO)

(a) $2010-2012$
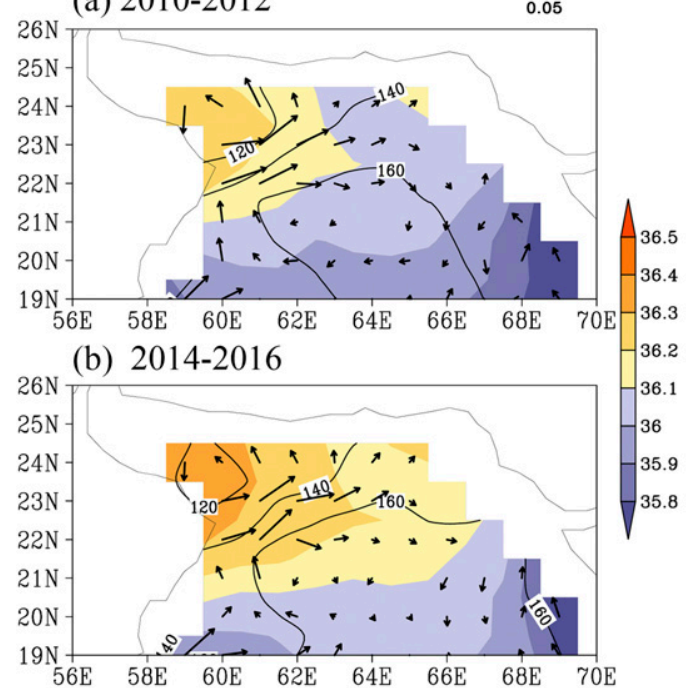

(c) difference

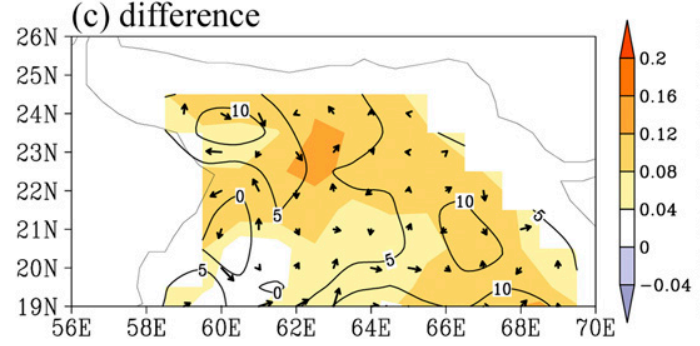

$\mathrm{S}(\mathrm{AMJ}) /$ depth\&current(FMA)

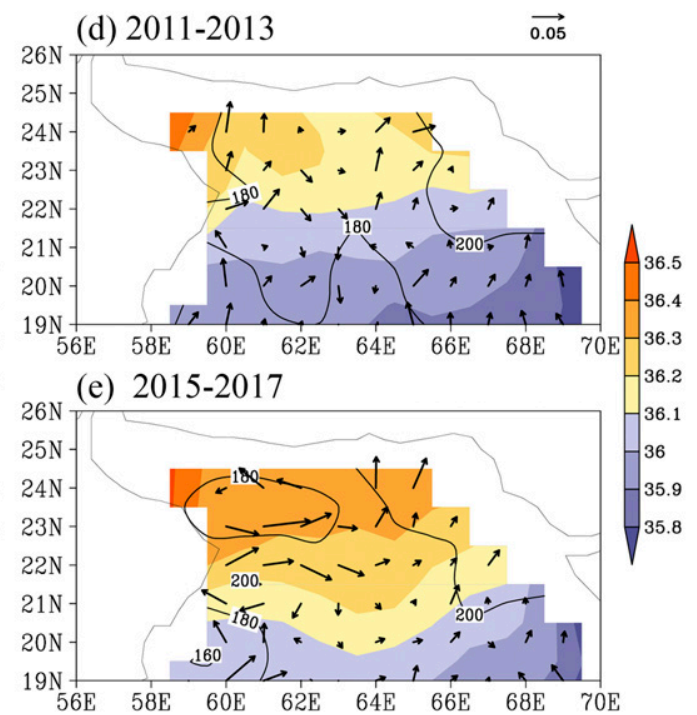

(f) difference

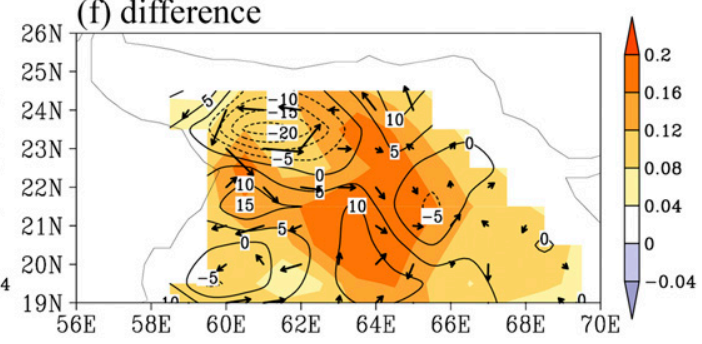

FIG. 10. As in Fig. 7, but for seasonal mean salinity (shaded; psu), layer depth (contours; m) and geostrophic currents $\left(\mathrm{m} \mathrm{s}^{-1}\right)$ in the layers between $\sigma_{0}=25.5$ and $26.0 \mathrm{~kg} \mathrm{~m}^{-3}$.

(Fig. 11a). The annual mean $E-P$ forcing and the zonal advection from the Gulf of Oman across the $60^{\circ} \mathrm{E}$ transect contributed to the increase of the salinity in the northern Arabian Sea, while the meridional advection tended to counteract by transporting fresher waters into the domain through the southern boundary (Fig. 11a).

The residual is rather large, which might be caused by undersampled boundary currents, and uncertainties with the datasets. Despite the uncertainties in the $E-P$ obtained from the five sources (Fig. 2c), the observed 4-yr mean $E-P$ exceeded the confidence level based on a Student's $t$ test (Fig. 11a). The observed magnitude of coastal currents along the Omani coast varied from more than $100 \mathrm{~cm} \mathrm{~s}^{-1}$ along the shore to $10-20 \mathrm{~cm} \mathrm{~s}^{-1}$ offshore (Flagg and Kim 1998). However, the observed Argo data were very scarce within the $200 \mathrm{~km}$ along the shore (Fig. 4), which might cause severe underestimation of the low-salinity water advection by the coastal currents. The large negative residual further indicated that the underestimation of the low-salinity water advection by the northward-flowing coastal currents cannot be neglected (Fig. 11a).
The annual mean value of the average salinity during the high-salinity event during 2014-17 was 0.07 psu higher than that during 2010-13. The salt balance changed dramatically during the 2014-17 and the mean tendency of the volume mean salinity was about $0.02 \mathrm{psu} \mathrm{yr}^{-1}$ (Fig. 11b). The increase of the salinity in the high-salinity event was mainly caused by the strengthened zonal positive salt advection (Fig. 11c). The strengthened zonal advection of the high-salinity water from the Gulf of Oman to the northern Arabian Sea contributed to the increase of the salinity by nearly $0.02 \mathrm{psu} \mathrm{yr}^{-1}$, which was comparable to the change of the salinity tendency (Fig. 11c). The difference of the $E-P$ forcing was not significant between two periods, which was consistent with the above result. The meridional advection of the low-salinity water across the southern boundary observed by the Argo dataset was strengthened slightly during 2014-17 than that during 2010-13, which was inconsistent with the result about the weakening of the subsurface low-salinity water intrusion. This discrepancy may be caused by the underestimation of the low-salinity advection by the undersampled coastal 
(a) 2010-2013

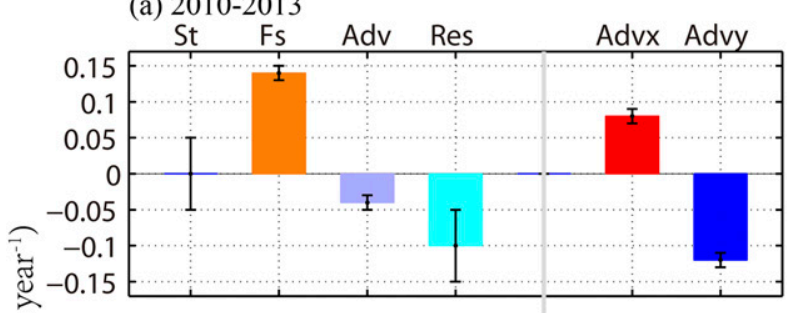

(b) $2014-2017$

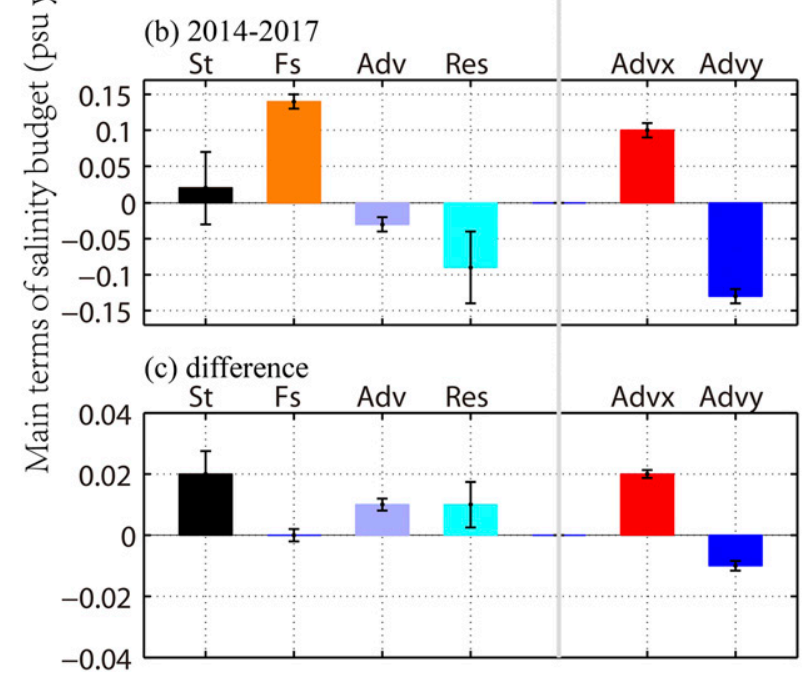

FIG. 11. Four-year averaged regional mean salinity budget terms $\left(\mathrm{psu} \mathrm{yr}^{-1}\right.$ ) and main salt advection terms before and during the prolonged high-salinity event and the differences between the latter period and the former in the northern Arabian Sea. St represents the tendency of the salinity, Fs represents the freshwater flux term, and Adv represents the total advection terms. Res represents the residual term calculated by $(\mathrm{St}-\mathrm{Adv}-\mathrm{Fs})$; Advx and Advy represent the zonal and meridional advection through the transects of $60^{\circ} \mathrm{E}$ and $20^{\circ} \mathrm{N}$, respectively. The error bars represent one standard error based on a Student's $t$ test.

currents. Thus, the difference of the residual terms between 2014-17 and 2010-13 was most likely generated by the weakened northward low-salinity water advection by coastal currents (Fig. 11c). It contributed to the increase of the salinity during the high-salinity event.

\section{Discussion}

The inhomogeneous distribution of the Argo profiles may have influences on the above analysis results. Particularly, the number of profiles in 2014-17 even exceeded the previous 12 years total (Fig. 3). To test the sensitivity due to data coverage, we used single floats, quasi-stationary in the region, and spanned across the two periods before and after 2014.

Among all float available, two Argo floats (IDs 2901411 and 2901454) recorded the salinity increase near the mouth of the Gulf of Oman after 2014 (Fig. 12). Just considering the salinity within an oval region covered by the eddies near the mouth of the Gulf of Oman (Fig. 12a), the salinity observed by float 2901411 showed that the salinity of the two high-salinity water masses increased after January 2014, as compared to the same seasons in 2012 and 2013 (Fig. 12c). Particularly, the surface ASHSW deepened to the upper layer of the intermediate high-salinity PGW, and the low-salinity water between them was much weaker during JanuaryApril in 2014 than that during the same months in 2012 and 2013 (Fig. 12c).

The increase of the salinity within the oval region after January 2014 was also observed by float 2901454 (Figs. 12a,d). Meanwhile, the salinity observed by float 2901454 after January 2014 was significantly higher than that observed by float 2901411 before January 2014 (Figs. 12c,d). These indicated that a prolonged highsalinity event did occur during 2014-17.

The increase of the salinity in the upper $400 \mathrm{~m}$ near the mouth of the Gulf of Oman was highly related to the stronger high-salinity water transport from the western Gulf of Oman and changes in the low-salinity advection from the western upwelling region and the eastern coastal region (Kumar and Prasad 1999; Prasad et al. 2001). The monsoonal winds are the dominant forcing for the circulations and their water mass transport in the northern Arabian Sea (Beal et al. 2013; Schott and McCreary 2001).

The South Asian summer monsoon showed a weakened trend in recent decades caused by the decrease of the land-sea thermal gradient with rapid warming in the tropical Indian Ocean (Shah and Srivastava 2019; Sun et al. 2019). Meanwhile, the ENSO events strongly affect the South Asian summer monsoon by modulating the land-sea thermal gradient and the tropical atmospheric circulation, which weakens it in the warm phase and strengthens it in the cold phase (Rasmusson and Carpenter 1983; Webster and Yang 1992). The mean monsoonal winds during 2014-17 were weaker than that during 2010-13 (Fig. 13), which implied a modulation of ENSO on the long-term trend. IOD may modulate the equatorial winds and then affect the remote wave processing along the northern Indian Ocean coast (Cheng et al. 2017, 2018), but it showed no direct influence on the high-salinity event in the northern Arabian Sea (Fig. 2c).

Besides the basinwide monsoonal forcing, the local winds in the northern Arabian Sea also affected the circulation and eddies in the western coastal regions. The monsoon winds in the northern Arabian Sea are controlled by the thermal forcing of the Iranian Plateau, which are different from that of the monsoon south of $20^{\circ} \mathrm{N}$ (Wu et al. 2012). The annual mean winds showed a significant northwesterly wind difference at the mouth of the Gulf of Oman between 2014-17 and 2010-13 
(a) trajectory of the float 2901411

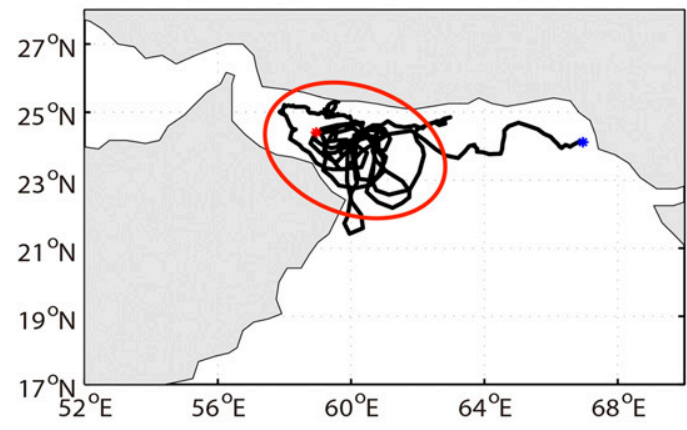

(b) trajectory of the float 2901454

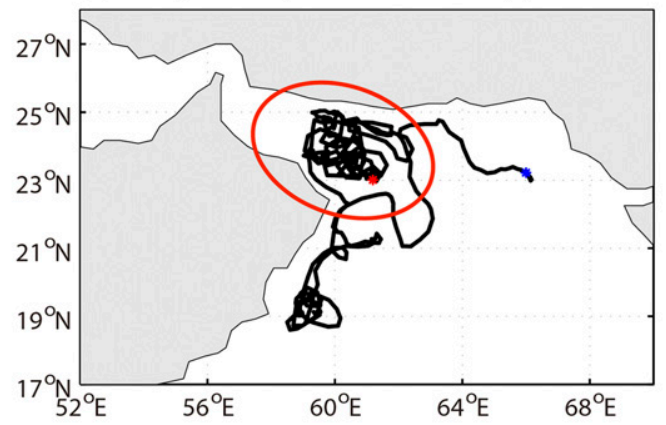

(c) salinity of the float_2901411

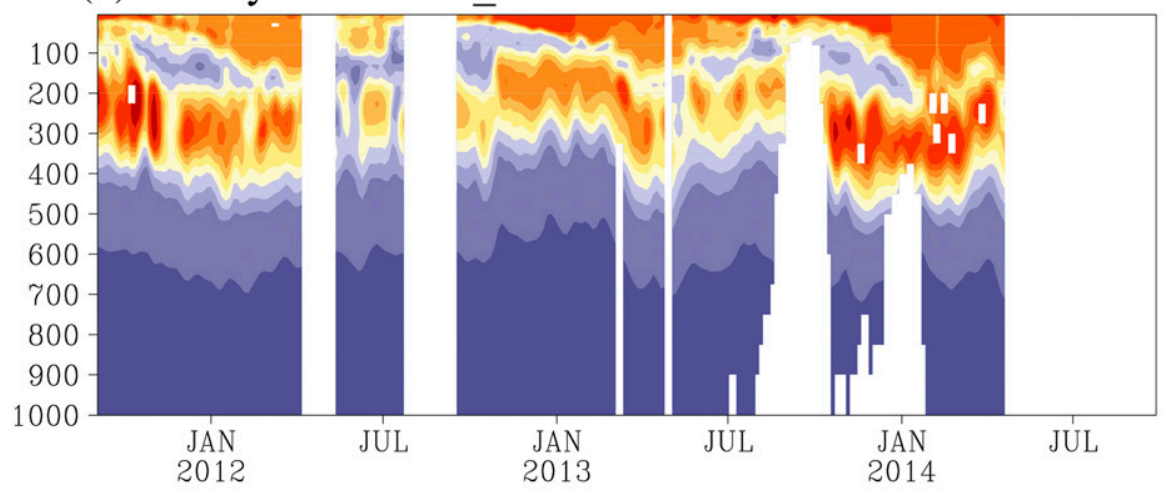

(d) salinity of the float_2901454

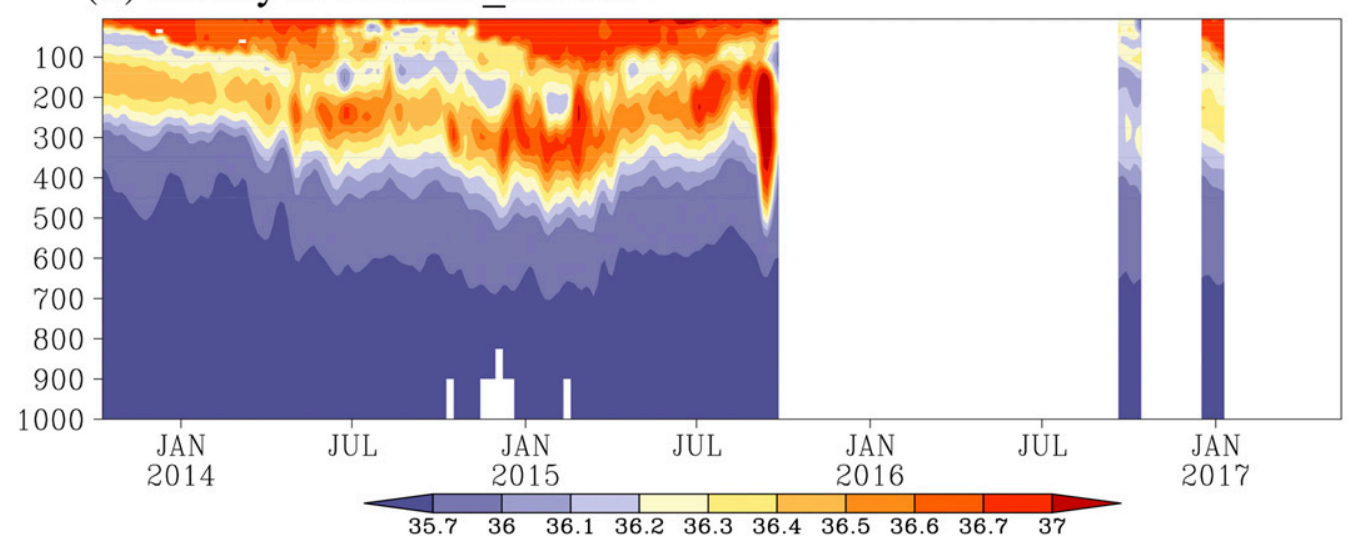

FIG. 12. Salinity (psu) observed by Argo floats in the elliptical area near the mouth of the Gulf of Oman. (a),(b) The trajectory of the floats 2901411 and 2901454 and (c),(d) the time-depth diagram of the salinity observed by the floats 2901411 and 2901454. The red ellipses in (a) and (b) show the elliptical area. The salinity data observed outside the elliptical area are removed in (c) and (d).

(Fig. 13), which favored the formation of the eddy dipole there, strengthening the advection of high-salinity water from the Gulf of Oman to the northern Arabian Sea. Meanwhile, the positive wind curl differences over the northern Arabian Sea and the negative one along the south Omani coast between 2014-17 and 2010-13 (Fig. 13c) contributed to strengthening the eddy dipole near the mouth of the Gulf of Oman.
Recent studies reported the impact of North Atlantic Oscillation on the surface temperature in the Arabian Sea and surrounding regions (Sun et al. 2019; Yao and Hoteit 2018), which might affect the monsoon and high-salinity water formation in the northern Arabian Sea. The above discussions indicated that the response of the upper-ocean circulation in the northern Arabian Sea to the regional monsoon variations, as 


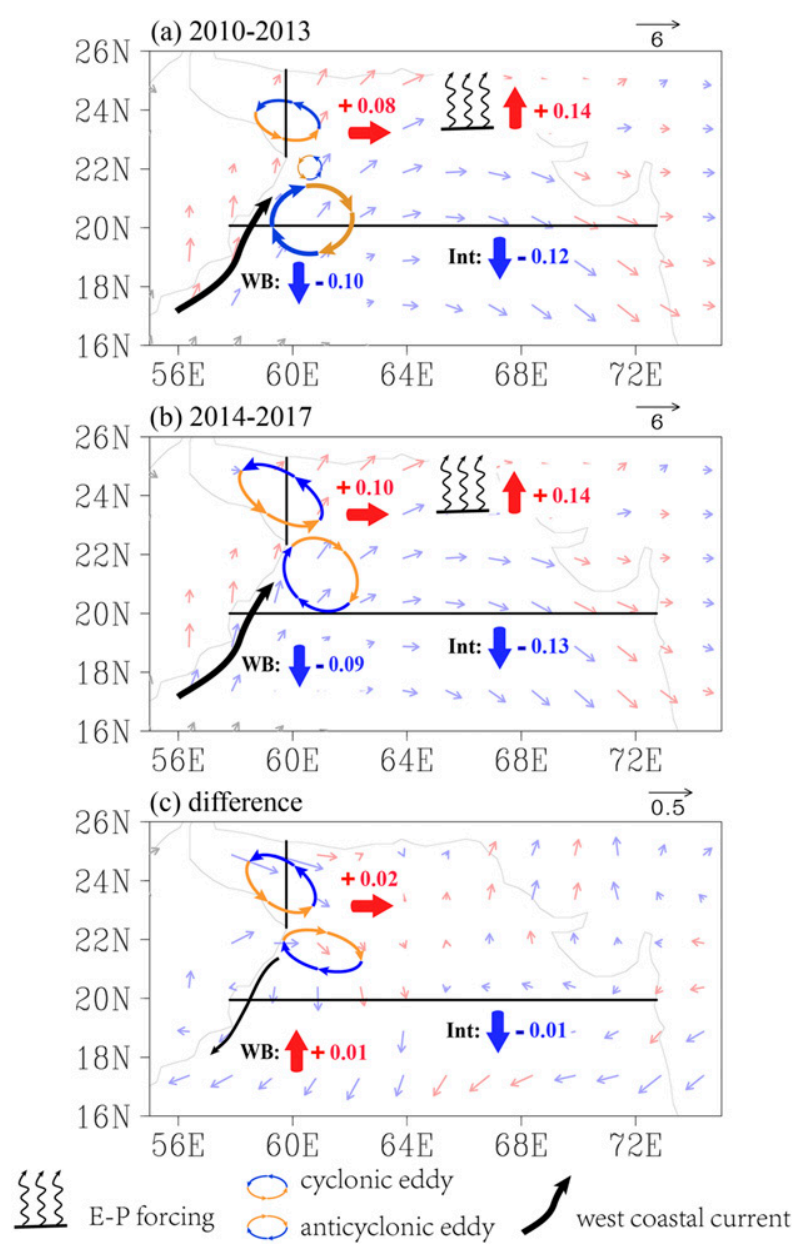

FIG. 13. Averaged surface wind (vectors; $\mathrm{m} \mathrm{s}^{-1}$ ), salt budget terms ( $\mathrm{psu} \mathrm{yr}^{-1}$ ) and the main processes that caused the salinity increase before and during the prolonged high-salinity event and their differences: (a) 2010-13, (b) 2014-17, and (c) the differences between the latter period and the former. The light blue and light red wind vectors indicate the negative and positive wind curls, respectively.

well as long-term climate change, needs further studies in the future.

\section{Conclusions}

A prolonged high-salinity event during 2014-17 was detected in the Arabian Sea north of $19^{\circ} \mathrm{N}$ based on Argo profile data and the gridded salinity product. During the event, the volumes of the surface ASHSW and the intermediate PGW increased in the northern Arabian Sea while the subsurface low-salinity decreased, causing dramatically positive salinity anomaly in the upper $400 \mathrm{~m}$.

The high-salinity event cannot be explained directly by the changes in regional air-sea freshwater exchanges.
Variations of ocean advection dominated the evolution of the event (Fig. 13). The water masses are saltier in the Gulf of Oman than in the northern Arabian Sea due to the excessive evaporation over precipitation. Thus, the changes of seasonal phase-locked eddies near the mouth of the Gulf favors the spreading of the surface ASHSW and the intermediate PGW from the Gulf of Oman into the northern Arabian Sea throughout the year, especially during early winter (November-January) and early summer (May-July).

In early winter during the high-salinity event, more surface and intermediate high-salinity water spreading into the northern Arabian Sea was caused by the weakened and westward-shifted cyclonic eddy across the mouth of the Gulf of Oman, as compared to that during 2010-13. The westward shifted eddy stretched to the remote western part of the Gulf of Oman, which helped the spreading of the saltier water mass to the northern Arabian Sea. In early summer, instead of the anticyclonic eddies off the Omani coast, an eddy dipole with a cyclone in the north and an anticyclone in the south occupied near the mouth of the Gulf of Oman, which strengthened the eastward flowing Ras Al Hadd Jet and its high-salinity water transport.

The annual mean difference between 2010-13 and 2014-17 showed an anomalous eddy dipole near the mouth of the Gulf of Oman, which strengthened the high-salinity advection into the northern Arabian Sea, contributing to the most of the salinity increase during the high-salinity event (Fig. 13). The regional wind stress forcing in the northern Arabian Sea contributed to the modulation of the eddies near the mouth of the Gulf of Oman. Besides, the northward low-salinity water advection along the coast, especially along the western coast, weakened during the high-salinity event than that during 2010-13, caused by the weakened monsoon, further contributing to the maintenance of the high-salinity event.

Acknowledgments. We acknowledge the International Argo Program giving the Argo temperature and salinity products (http://www.argo.ucsd.edu). The GPCP precipitation was obtained from the NASA/GSFC (http:// precip.gsfc.nasa.gov). The OAFlux was provided by WHOI OAFlux Project of Woods Hole Oceanographic Institution (http://oaflux.whoi.edu). The OSCAR currents were provided by NOAA's Ocean Surface Current Analyses Real Time (http://www.oscar.noaa.gov/ index.html). The ECMWF ERA5 was available at https://cds.climate.copernicus.eu/cdsapp\#!/home. The NCEP Reanalysis Derived data was provided by the NOAA/OAR/ESRL PSD (https://www.esrl.noaa.gov/ psd). The SSHA was provided by the AVISO (http:// www.aviso.oceanobs.com/en). The CCMP wind data are 
available from the RSS (http:/www.remss.com/measurements/ ccmp/). The DMI (http://www.emc.ncep.noaa.gov/research/ cmb/sst_analysis/) was available at NOAA/OOPC (https:// stateoftheocean.osmc.noaa.gov/sur/ind/dmi.php). This work is supported by the Chinese Academy of Sciences (XDA19060502, XDA13010404, ZDRW-XH-2019-2), the State Oceanic Administration of China (GASIIPOVAI-02), the National Natural Science Foundation of China (41976024, 41525019, 41830538, and 41506019), and the Southern Marine Science and Engineering Guangdong Laboratory (Guangzhou) (GML2019ZD0302, GML2019ZD0303). MF is supported by the Centre for Southern Hemisphere Oceans Research (CSHOR), which is a joint initiative between the Qingdao National Laboratory for Marine Science and Technology (QNLM), CSIRO, University of New South Wales and University of Tasmania.

\section{REFERENCES}

Adler, R. F., and Coauthors, 2003: The version-2 Global Precipitation Climatology Project (GPCP) monthly precipitation analysis (1979-present). J. Hydrometeor., 4, 11471167, https://doi.org/10.1175/1525-7541(2003)004<1147: TVGPCP $>2.0 . \mathrm{CO} ; 2$.

Atlas, R., R. N. Hoffman, J. Ardizzone, S. M. Leidner, J. C. Jusem, D. K. Smith, and D. Gombos, 2011: A cross-calibrated, multiplatform ocean surface wind velocity product for meteorological and oceanographic applications. Bull. Amer. Meteor. Soc., 92, 157-174, https://doi.org/10.1175/2010BAMS2946.1.

Banse, K., and J. R. Postel, 2009: Wintertime convection and ventilation of the upper pycnocline in the northernmost Arabian Sea. Indian Ocean Biogeochemical Processes and Ecological Variability, Geophys. Monogr., Vol. 185, Amer. Geophys. Union, 87-117.

Beal, L. M., A. Ffield, and A. L. Gordon, 2000: Spreading of red sea overflow waters in the Indian Ocean. J. Geophys. Res., 105, 8549-8564, https://doi.org/10.1029/1999JC900306.

_ - V. Hormann, R. Lumpkin, and G. R. Foltz, 2013: The response of the surface circulation of the Arabian Sea to monsoonal forcing. J. Phys. Oceanogr., 43, 2008-2022, https:// doi.org/10.1175/JPO-D-13-033.1.

Böhm, E., J. M. Morrison, V. Manghnani, H. S. Kim, and C. N. Flagg, 1999: The Ras al Hadd Jet: Remotely sensed and acoustic Doppler current profiler observations in 1994-1995. Deep-Sea Res. II, 46, 1531-1549, https://doi.org/10.1016/ S0967-0645(99)00034-X.

Bonjean, F., and G. S. E. Lagerloef, 2002: Diagnostic model and analysis of the surface currents in the tropical Pacific Ocean. J. Phys. Oceanogr., 32, 2938-2954, https://doi.org/10.1175/ 1520-0485(2002)032<2938:DMAAOT $>2.0 . C O ; 2$.

Carton, X., P. L'Hegaret, and R. Baraille, 2012: Mesoscale variability of water masses in the Arabian Sea as revealed by ARGO floats. Ocean Sci., 8, 227-248, https://doi.org/10.5194/ os-8-227-2012.

Cheng, X., J. P. McCreary, B. Qiu, Y. Qi, and Y. Du, 2017: Intraseasonal-to-semiannual variability of sea-surface height in the astern, equatorial Indian Ocean and southern Bay of Bengal. J. Geophys. Res. Oceans, 122, 4051-4067, https:// doi.org/10.1002/2016JC012662.
- and X. Chen, 2018: Dynamics of edd generation in the central Bay of Bengal. J. Geophys. Res. Oceans, 123, 6861-6875, https://doi.org/10.1029/2018JC014100.

Chu, P. C., 1995: P-vector method for determining absolute velocity from hydrographic data. Mar. Technol. Soc. J., 29, 3-14. , and R. F. Li, 2000: South China Sea isopycnal-surface circulation. J. Phys. Oceanogr., 30, 2419-2438, https://doi.org/ 10.1175/1520-0485(2000)030<2419:SCSISC $>2.0 . C O ; 2$.

,$- \ldots$, and X. B. You, 2002: Northwest Pacific subtropical countercurrent on isopycnal surface in summer. Geophys. Res. Lett., 29, 1842, https://doi.org/10.1029/2002GL014831.

Fischer, A. S., R. A. Weller, D. L. Rudnick, C. C. Eriksen, C. M. Lee, K. H. Brink, C. A. Fox, and R. R. Leben, 2002: Mesoscale eddies, coastal upwelling, and the upper-ocean heat budget in the Arabian Sea. Deep-Sea Res. II, 49, 2231-2264, https:// doi.org/10.1016/S0967-0645(02)00036-X.

Flagg, C. N., and H.-S. Kim, 1998: Upper ocean currents in the northern Arabian Sea from shipboard ADCP measurements collected during the 1994-1996 U.S. JGOFS and ONR programs. Deep-Sea Res. II, 45, 1917-1959, https://doi.org/ 10.1016/S0967-0645(98)00059-9.

Gordon, A., 2005: Oceanography of the Indonesian Seas and their throughflow. Oceanography, 18, 14-27, https://doi.org/ 10.5670/oceanog.2005.01.

Han, W. Q., J. P. McCreary, and K. E. Kohler, 2001: Influence of precipitation minus evaporation and Bay of Bengal rivers on dynamics, thermodynamics, and mixed layer physics in the upper Indian Ocean. J. Geophys. Res., 106, 6895-6916, https:// doi.org/10.1029/2000JC000403.

Huffman, G. J., R. F. Adler, D. T. Bolvin, and G. J. Gu, 2009: Improving the global precipitation record: GPCP version 2.1. Geophys. Res. Lett., 36, L17808, https://doi.org/10.1029/2009GL040000.

Jensen, T. G., 2003: Cross-equatorial pathways of salt and tracers from the northern Indian Ocean: Modelling results. Deep-Sea Res. II, 50, 2111-2127, https://doi.org/10.1016/S0967-0645(03) 00048-1.

Joseph, S., and H. J. Freeland, 2005: Salinity variability in the Arabian Sea. Geophys. Res. Lett., 32, L09607, https://doi.org/ 10.1029/2005GL022972.

Jung, S. J. A., G. M. Ganssen, and G. R. Davies, 2001: Multidecadal variations in the early Holocene outflow of Red Sea water into the Arabian Sea. Paleoceanography, 16, 658-668, https:// doi.org/10.1029/2000PA000592.

Kalnay, E., and Coauthors, 1996: The NCEP/NCAR 40-year reanalysis project. Bull. Amer. Meteor. Soc., 77, 437-471, https:// doi.org/10.1175/1520-0477(1996)077<0437:TNYRP>2.0.CO;2.

Kanamitsu, M., W. Ebisuzaki, J. Woollen, S. K. Yang, J. J. Hnilo, M. Fiorino, and G. L. Potter, 2002: NCEP-DOE AMIP-II Reanalysis (R-2). Bull. Amer. Meteor. Soc., 83, 1631-1643, https://doi.org/10.1175/BAMS-83-11-1631.

Koné, V., O. Aumont, M. Lévy, and L. Resplandy, 2009: Physical and biogeochemical controls of the phytoplankton seasonal cycle in the Indian Ocean: A modeling study. Indian Ocean Biogeochemical Processes and Ecological Variability, Geophys. Monogr., Vol. 185, Amer. Geophys. Union, 147-166.

Kumar, S. P., and T. G. Prasad, 1996: Winter cooling in the northern Arabian Sea. Curr. Sci., 71, 834-841.

_, and 1999: Formation and spreading of Arabian Sea high-salinity water mass. J. Geophys. Res., 104, 1455-1464, https://doi.org/10.1029/1998JC900022.

Levitus, S., 1983: Climatological Atlas of the world ocean. Eos, Trans. Amer. Geophys. Union, 64, 962-963, https://doi.org/ 10.1029/EO064i049p00962-02. 
L'Hégaret, P., L. Lacour, X. Carton, G. Roullet, R. Baraille, and S. Correard, 2013: A seasonal dipolar eddy near Ras Al Hamra (Sea of Oman). Ocean Dyn., 63, 633-659, https://doi.org/ 10.1007/s10236-013-0616-2.

_ , R. Duarte, X. Carton, C. Vic, D. Ciani, R. Baraille, and S. Corréard, 2015: Mesoscale variability in the Arabian Sea from HYCOM model results and observations: Impact on the Persian Gulf water path. Ocean Sci., 11, 667-693, https:// doi.org/10.5194/os-11-667-2015.

— , X. Carton, S. Louazel, and G. Boutin, 2016: Mesoscale eddies and submesoscale structures of Persian Gulf Water off the Omani coast in spring 2011. Ocean Sci., 12, 687-701, https:// doi.org/10.5194/os-12-687-2016.

Li, Y., H. Liu, and P. Lin, 2018: Interannual and decadal variability of the north equatorial undercurrents in an eddy-resolving ocean model. Sci. Rep., 8, 17112, https://doi.org/10.1038/ s41598-018-35469-2.

Manghnani, V., J. M. Morrison, T. S. Hopkins, and E. Bohm, 1998: Advection of upwelled waters in the form of plumes off Oman during the southwest monsoon. Deep-Sea Res. II, 45, 2027 2052, https://doi.org/10.1016/S0967-0645(98)00062-9.

McCreary, J. P., P. K. Kundu, and R. L. Molinari, 1993: A numerical investigation of dynamics, thermodynamics and mixed-layer processes in the Indian-Ocean. Prog. Oceanogr., 31, 181-244, https://doi.org/10.1016/0079-6611(93)90002-U.

Morrison, J. M., 1997: Inter-monsoonal changes in the T-S properties of the near-surface waters of the northern Arabian Sea. Geophys. Res. Lett., 24, 2553-2556, https://doi.org/10.1029/97GL01876.

Prasad, T. G., and M. Ikeda, 2002a: The wintertime water mass formation in the northern Arabian Sea: A model study. $J$. Phys. Oceanogr., 32, 1028-1040, https://doi.org/10.1175/15200485(2002)032,1028:TWWMFI.2.0.CO;2.

_- and - 2002b: A numerical study of the seasonal variability of Arabian Sea high-salinity water.J. Geophys. Res., 107, 3197, https://doi.org/10.1029/2001JC001139.

- - $\longrightarrow$ and S. P. Kumar, 2001: Seasonal spreading of the Persian Gulf water mass in the Arabian Sea. J. Geophys. Res., 106, 17 059-17 071, https://doi.org/10.1029/2000JC000480.

Qasim, S. Z., 1982: Oceanography of the northern Arabian Sea. Deep-Sea Res., 29A, 1041-1068, https://doi.org/10.1016/01980149(82)90027-9.

Rasmusson, E. M., and T. H. Carpenter, 1983: The relationship between eastern equatorial Pacific Sea-surface temperatures and rainfall over India and Sri-Lanka. Mon. Wea. Rev., 111, 517-528, https://doi.org/10.1175/1520-0493(1983)111<0517: TRBEEP $>2.0 . \mathrm{CO} ; 2$.

Reynolds, R. W., N. A. Rayner, T. M. Smith, D. C. Stokes, and W. Q. Wang, 2002: An improved in situ and satellite SST analysis for climate. J. Climate, 15, 1609-1625, https://doi.org/ 10.1175/1520-0442(2002)015<1609:AIISAS > 2.0.CO;2.

Rochford, D. J., 1964: Salinity maxima in the upper 1000 metres of the North Indian Ocean. Mar. Freshwater Res., 15, 1-24, https://doi.org/10.1071/MF9640001.

Roemmich, D., and J. Gilson, 2009: The 2004-2008 mean and annual cycle of temperature, salinity, and steric height in the global ocean from the Argo Program. Prog. Oceanogr., 82, 81100, https://doi.org/10.1016/j.pocean.2009.03.004.

Schott, F. A., and J. Fischer, 2000: Winter monsoon circulation of the northern Arabian Sea and Somali current. J. Geophys. Res., 105, 6359-6376, https://doi.org/10.1029/1999JC900312.

— , and J. P. McCreary, 2001: The monsoon circulation of the Indian Ocean. Prog. Oceanogr., 51, 1-123, https://doi.org/ 10.1016/S0079-6611(01)00083-0.
Shah, R., and R. Srivastava, 2019: Effect of climate change on cloud properties over Arabian Sea and Central India. Pure Appl. Geophys., 176, 2729-2738, https://doi.org/10.1007/s00024-01902125-3.

Shapiro, G. I., and S. L. Meschanov, 1991: Distribution and spreading of Red-Sea water and salt lens formation in the northwest Indian-Ocean. Deep-Sea Res., 38A, 21-34, https:// doi.org/10.1016/0198-0149(91)90052-H.

Shi, W., J. M. Morrison, E. Bohm, and V. Manghnani, 1999: Remotely sensed features in the US JGOFS Arabian Sea process study. Deep-Sea Res. II, 46, 1551-1575, https://doi.org/ 10.1016/S0967-0645(99)00035-1.

Sprintall, J., S. E. Wijffels, R. Molcard, and I. Jaya, 2009: Direct estimates of the Indonesian Throughflow entering the Indian Ocean: 2004-2006. J. Geophys. Res., 114, C07001, https:// doi.org/10.1029/2008JC005257.

Stramma, L., P. Brandt, F. Schott, D. Quadfasel, and J. Fischer, 2002: Winter and summer monsoon water mass, heat and freshwater transport changes in the Arabian Sea near $8^{\circ} \mathrm{N}$. Deep-Sea Res. II, 49, 1173-1195, https://doi.org/10.1016/ S0967-0645(01)00169-2.

Sun, C., and Coauthors, 2019: Recent acceleration of Arabian Sea warming induced by the Atlantic-western Pacific Trans-Basin multidecadal variability. Geophys. Res. Lett., 46, 1662-1671, https://doi.org/10.1029/2018GL081175.

Swift, S. A., and A. S. Bower, 2003: Formation and circulation of dense water in the Persian/Arabian Gulf. J. Geophys. Res., 108, 3004, https://doi.org/10.1029/2002JC001360.

Varma, K. K., V. K. Das, and A. D. Gouveia, 1980: Thermohaline structure \& watermasses in the northern Arabian Sea during February-April. Indian J. Geo-Mar. Sci., 9, 148-155, http:// nopr.niscair.res.in/handle/123456789/39246.

Wang, Z. K., S. F. DiMarco, A. E. Jochens, and S. Ingle, 2013: High salinity events in the northern Arabian Sea and Sea of Oman. Deep-Sea Res. I, 74, 14-24, https://doi.org/10.1016/ j.dsr.2012.12.004.

Webster, P. J., and S. Yang, 1992: Monsoon and Enso - selectively interactive systems. Quart. J. Roy. Meteor. Soc., 118, 877-926, https://doi.org/10.1002/qj.49711850705.

Wentz, F. J., Scott J., Hoffman R., Leidner M., Atlas R., and Ardizzone. J., 2015: Remote Sensing Systems CrossCalibrated Multi-Platform (CCMP) 6-hourly ocean vector wind analysis product on $0.25 \mathrm{deg}$ grid, version 2.0. Remote Sensing Systems, accessed 15 November 2017, http://www.remss.com/measurements/ccmp.

Wu, G., Y. Liu, B. He, Q. Bao, A. Duan, and F. F. Jin, 2012: Thermal controls on the Asian summer monsoon. Sci. Rep., 2, 404, https://doi.org/10.1038/srep00404.

Wyrtki, K., 1971: Oceanographic Atlas of the International Indian Ocean Expedition. National Science Foundation, 531 pp.

Yao, F., and I. Hoteit, 2018: Rapid Red Sea deep water renewals caused by volcanic eruptions and the North Atlantic Oscillation. Sci. Adv., 4, eaar5637, https://doi.org/10.1126/ sciadv.aar5637.

Yao, F. C., and W. E. Johns, 2010: A HYCOM modeling study of the Persian Gulf: 2. Formation and export of Persian Gulf water. J. Geophys. Res., 115, C11018, https://doi.org/10.1029/ 2009JC005788.

Yu, L., and R. A. Weller, 2007: Objectively analyzed air-sea heat fluxes for the global ice-free oceans (1981-2005). Bull. Amer. Meteor. Soc., 88, 527-540, https://doi.org/10.1175/BAMS-884-527. 